\title{
Oceanic dispersal of juvenile leatherback turtles: going beyond passive drift modeling
}

\author{
Philippe Gaspar ${ }^{1, *}$, Scott R. Benson ${ }^{2}$, Peter H. Dutton ${ }^{3}$, Adrien Réveillère ${ }^{1}$, \\ Guillaume Jacob ${ }^{1}$, Cherina Meetoo ${ }^{1}$, Amaury Dehecq ${ }^{1}$, Sabrina Fossette ${ }^{4}$
}

\author{
${ }^{1}$ Department of Marine Ecosystems, Satellite Oceanography Division, Collecte Localisation Satellites, 31520 Ramonville, France \\ ${ }^{2}$ Protected Resources Division, Southwest Fisheries Science Center, National Marine Fisheries Service, \\ National Oceanic and Atmospheric Administration c/o Moss Landing Marine Laboratories, Moss Landing, California 95039, USA \\ ${ }^{3}$ Protected Resources Division, Southwest Fisheries Science Center, National Marine Fisheries Service, \\ National Oceanic and Atmospheric Administration, La Jolla, California 92037, USA \\ ${ }^{4}$ Department of Biosciences, College of Science, Swansea University, Singleton Park, Swansea SA2 8PP, UK
}

\begin{abstract}
The current paper presents the first detailed investigation of open-ocean dispersal of hatchlings and juveniles of the critically endangered western Pacific leatherback turtle Dermochelys coriacea populations nesting in New Guinea. Dispersal patterns were simulated by releasing particles drifting passively, or almost passively, into a state-of-the-art World Ocean circulation model. Analysis of the simulation results combined with sighting, genetic, bycatch, and adult satellite tracking information reveals that: (1) Hatchlings emerging from the main New Guinea nesting beaches are likely to be entrained by highly variable oceanic currents into the North Pacific, South Pacific, or Indian Oceans. Those drifting into the Indian Ocean likely suffer very high mortality. This suggests that, as ocean current variability determines the partition of hatchlings into different dispersal areas, it also largely influences juvenile survival rate at the population level. (2) Within 1 to $2 \mathrm{yr}$, most passively drifting juveniles reach temperate oceanic regions where the water temperature in winter drops well below the minimum temperature likely tolerated by such small individuals. This leads us to hypothesize that, after an initial period of mostly passive drift, juveniles initiate active swimming towards lower (warmer) latitudes before winter and back again towards higher latitudes, where food abounds, during spring. Such seasonal migrations would significantly slow the eastward progression of individuals circulating in the North Pacific current. This slower drift scenario better explains the size distribution of leatherbacks observed, or incidentally caught by pelagic fisheries, in the North Pacific. This dispersal mechanism combining passive drift with active habitat-driven seasonal migrations might well apply to many other sea turtle populations and deserves further study.
\end{abstract}

KEY WORDS: Leatherback turtle · Juvenile dispersal · Seasonal migrations · Ocean circulation · Western Pacific

\section{INTRODUCTION}

The knowledge gaps on the early juvenile life history and spatial ecology of sea turtles continue to impede research and conservation of these threatened species (Hamann et al. 2010). After emerging from their nests, sea turtle hatchlings crawl to the water and swim vigorously towards the open ocean where they become 'lost' to observation for several years. Tracking such small individuals in the open ocean is extremely difficult (e.g. Seney et al. 2010) so that observations of where they disperse, what habitat they occupy and how they exploit it are extremely sparse. A now widely accepted model is that during their first years of life juveniles 'become plankton and drift more or less passively in the open sea' (Carr 
1986a) so that their dispersal follows large-scale oceanic circulation patterns. This hypothesis is corroborated by multiple studies showing that the size and spatial distributions of oceanic juveniles captured at sea or found stranded display patterns that are consistent with transport by major currents downstream of the nesting beaches (Carr 1986b, Collard \& Ogren 1990, Bolten et al. 1993). Genetic analyses have also been able to track these juveniles back to their natal rookeries that, indeed, prove to be upstream of the place where they were found (Bowen et al. 1995, 2007, Bolten et al. 1998, Boyle et al. 2009). More recently, studies combining genetic data with surface current analyses have indicated that current patterns also play an important role in determining the genetic structure of juvenile foraging aggregations (Carreras et al. 2006, Bass et al. 2006, Blumenthal et al. 2009, Monzón Argüello et al. 2010, Amorocho et al. 2012), further reinforcing the idea that the juveniles' dispersal is largely driven by oceanic currents. These studies however focus on juvenile sea turtle species that disperse to neritic foraging grounds. The dispersal of leatherbacks Dermochelys coriacea has been much less investigated, probably because juveniles remain essentially pelagic and thus more cryptic.

In the present paper we set out to investigate the dispersal of hatchlings and juveniles of the western Pacific leatherback population nesting in New Guinea. This nesting stock is of special conservation concern, because it contains the last remaining sizeable leatherback population in the Pacific (Hitipeuw et al. 2007). Significant efforts have been devoted to characterize its genetic structure (Dutton et al. 1999, 2007) and to identify adults' migration pathways (Benson et al. 2007a,b, 2011), but the juveniles' spatial ecology remains largely unknown. This study is a first attempt to gain insight into dispersal patterns of western Pacific juveniles. It is especially challenging as the western Pacific leatherback population nests in one of the most complex and dynamic areas of the world's oceans, connecting the Pacific to the Indian Ocean. In this area, strong and highly variable currents can push hatchlings in widely different directions depending on when and where they terminate their swimming frenzy. As a result young sea turtles originating from the same nesting beach can rapidly reach different oceanic areas within a few months and thereby experience very different life histories. Variability of oceanic circulation adjacent to the nesting sites thus likely has a profound, but so-far uninvestigated, impact on the dynamics of this sea turtle population.
As in previous juveniles' dispersal studies (Hays \& Marsh 1997, Blumenthal et al. 2009, Godley et al. 2010, Hays et al. 2010), we start from the assumption that, after their swimming frenzy, hatchlings behave as drifters passively transported by surface ocean currents. We use a state-of-the-art operational ocean model to simulate the dispersal patterns of such passive drifters released off 2 main nesting beaches and initially perform $1 \mathrm{yr}$ drift simulations to investigate the interannual variability of the dispersal schemes. Passive drift is a reasonable hypothesis for the first year of life during which the swimming activity is probably very limited. Even for older, more powerful, individuals the current-induced drift remains a major component of the movement (e.g. Gaspar et al. 2006) so that passive drift simulations covering periods well exceeding 1 yr have proven to be useful in a number of studies (Hays \& Marsh 1997, Putman et al. 2010). We therefore extend our dispersal simulations to $6 \mathrm{yr}$, first using the strictly passive drift hypothesis, then adding random swimming activity to simulate occasional foraging movements. Both simulations yield quite similar dispersal patterns, showing striking coincidences with some observations and inconsistencies with others. Analysis of inconsistencies suggests that actual juveniles' trajectories must deviate from simulated trajectories after an initial period of several months during which passive drift likely prevails. We finally propose a somewhat more elaborate description of the juveniles' dispersal mechanisms that includes seasonally directed movements and better fits observations.

\section{MATERIALS AND METHODS}

\section{Nesting sites}

Nesting aggregations of the western Pacific leatherback Dermochelys coriacea occur primarily in New Guinea and the Solomon Islands. They comprise a metapopulation composed of a single genetic stock distinct from the eastern Pacific population, and the almost extinct Malaysian population (Dutton et al. 1999, 2007). The 2 largest identified nesting areas of the western Pacific stock are located on the north coast of New Guinea (Fig. 1). Bird's Head Peninsula (Papua-Barat, Indonesia), at the westernmost tip of the island, hosts about $75 \%$ of the nesting activity of this regional stock, estimated at 5000 to 9000 nests $\mathrm{yr}^{-1}$. Further east, the Huon Gulf (Papua New Guinea) accounts for another $5 \%$ of this activity (Dutton et al. 2007). Drift simulations were performed for hatch- 


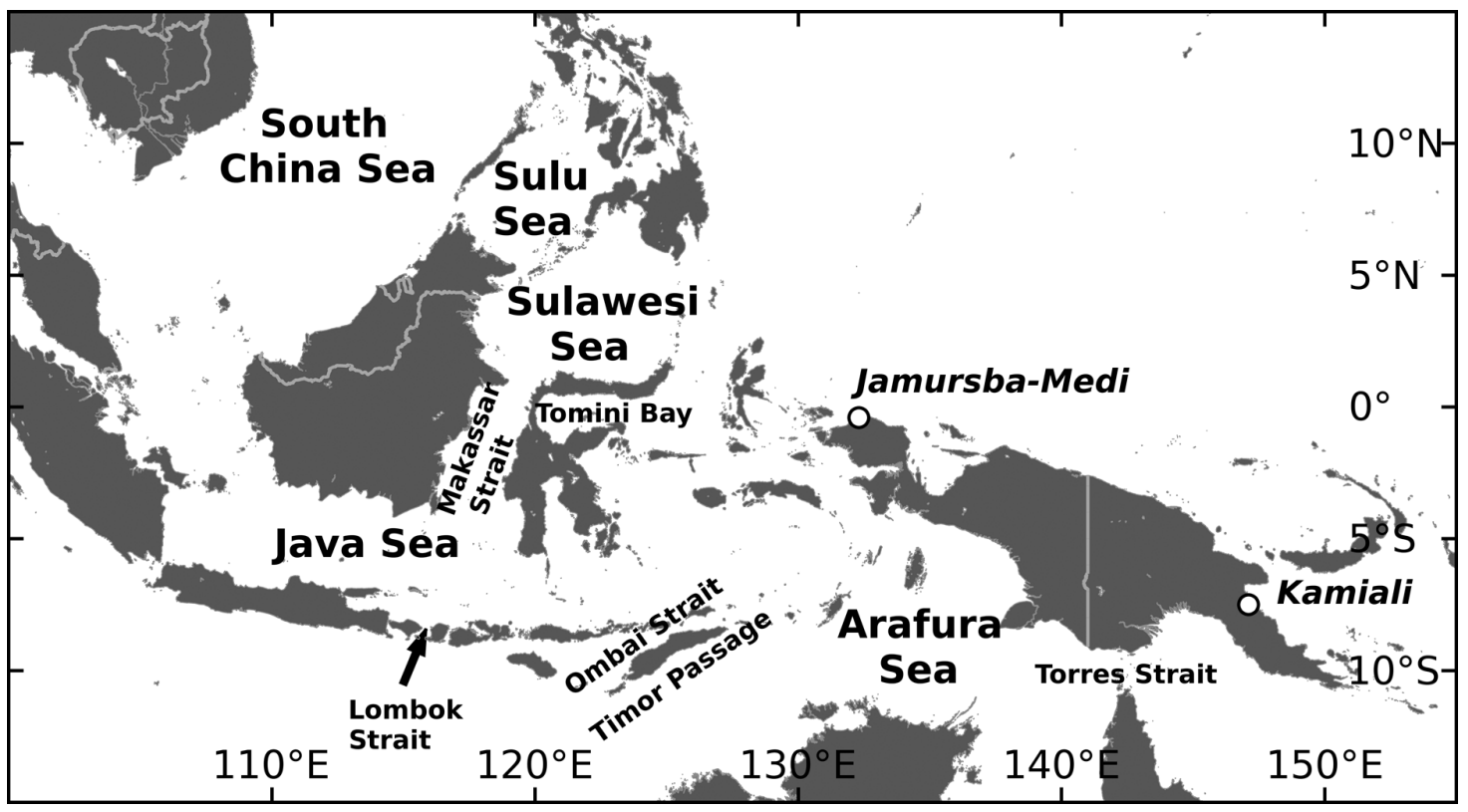

Fig. 1. New Guinea and surrounding area, featuring the 2 studied nesting sites, adjacent seas and main straits

lings emerging from Jamursba-Medi and Kamiali, the 2 main nesting beaches located on Bird's Head Peninsula and in the Huon Gulf, respectively. The migration patterns of adult females nesting on these beaches are known from various satellite-tracking experiments (Benson et al. 2007a,b, 2011).

\section{Surface currents}

Trajectories of passively drifting hatchlings and juveniles were computed using the surface current fields produced by the GLORYS-1 (G1) reanalysis of the World Ocean circulation (Ferry et al. 2008). This reanalysis covers the period 1 January 2002 to 31 December 2008 and was performed by the Mercator-Ocean operational oceanography centre (www. mercator-ocean.fr/) with the NEMO numerical ocean model (www.nemo-ocean.eu/). The model version used in G1 has a horizontal resolution of $0.25^{\circ}$ and 50 vertical layers. It is forced by daily surface meteorological data from ECMWF (European Centre for Medium-Range Weather Forecasts).

Satellite-derived sea level anomalies, sea-surface temperatures and in situ measurements of vertical temperature and salinity profiles are assimilated into G1 so that this state-of-the-art reanalysis provides a close-to-reality, $7 \mathrm{yr}$ long, 3-dimensional simulation of the World Ocean dynamics and thermodynamics (Ferry et al. 2010). The use of such a long reanalysis including data assimilation overcomes important lim- itations encountered in previous hatchlings' drift simulations: the equatorial area is covered unlike in simulations based on satellite-derived currents (e.g. Godley et al. 2010) and pluriannual trajectory simulations can be performed without concern over excessive error accumulation resulting from possible model drift in the absence of data assimilation.

The G1 surface current field features the main currents and oceanic features that are known to exist in our area of interest (Fig. 2). The complex circulation in the western Equatorial Pacific Ocean (e.g. Arruda $\&$ Nof 2003) is faithfully reproduced. The eastwardflowing North Equatorial Countercurrent (NECC) is present around $5^{\circ} \mathrm{N}$. It separates the broad westward-flowing North Equatorial Current (NEC) from the more intense, but narrower, South Equatorial Current (SEC). As it reaches the Philippines, the NEC bifurcates into the northward-flowing Kuroshio and the southward-flowing Mindanao Current (MC). The quasi-permanent Halmahera (HE) and Mindanao (ME) Eddies are both correctly simulated in the retroflection area of the SEC and MC.

The New Guinea Coastal Current (NGCC) is also well resolved in the $\mathrm{G} 1$ reanalysis. This current proves to be of major importance in the present study as it connects the 2 studied nesting beaches. During the southeast monsoon (May to September), this current flows northwestward along the coast, generally reaching speeds close to or above $0.5 \mathrm{~m} \mathrm{~s}^{-1}$. During the northwest monsoon (November to March), it weakens and usually reverses direction to flow southeast- 

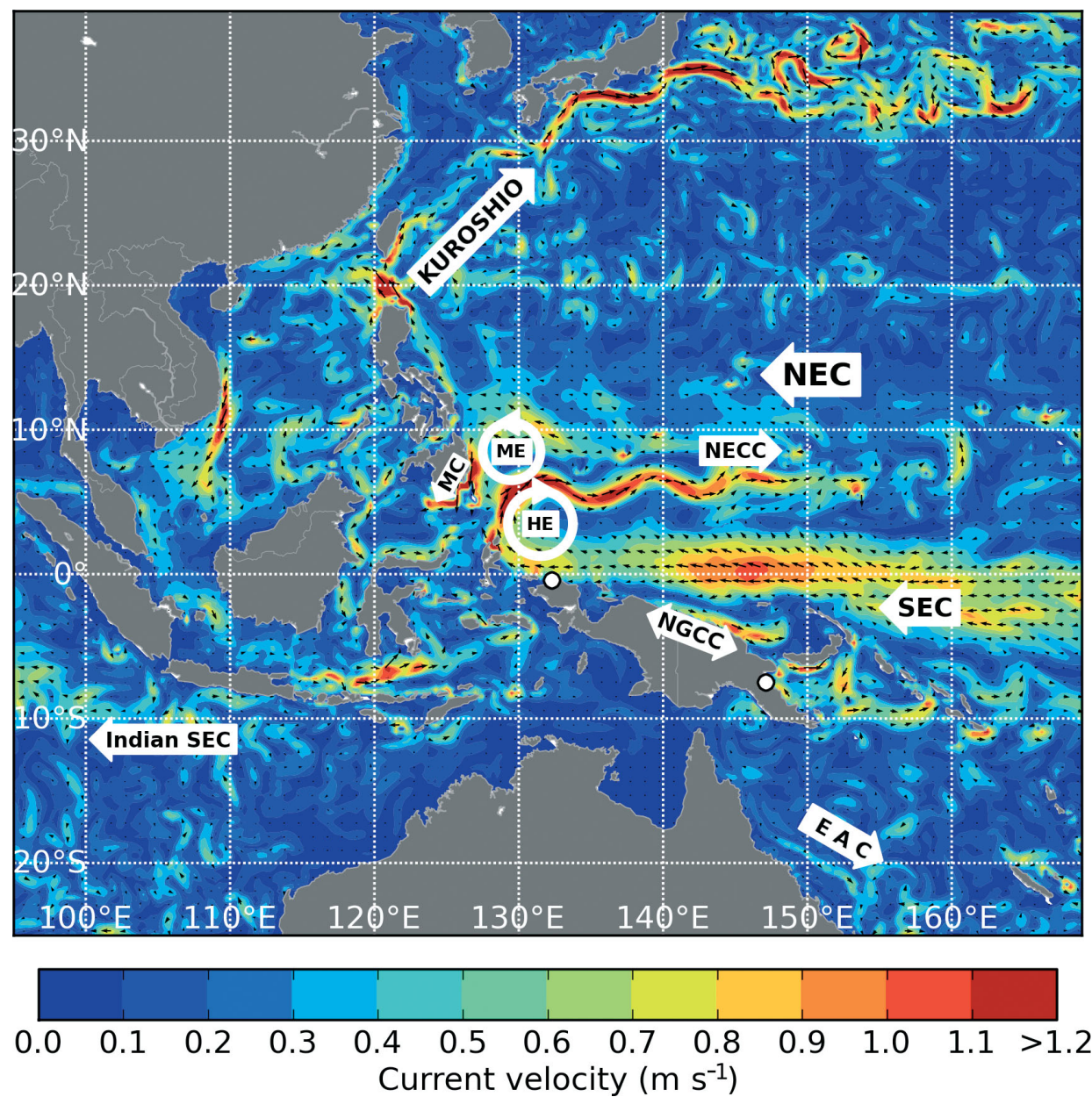

Fig. 2. A surface current field from the G1 simulation (daily mean currents on February 8, 2006). NECC: North Equatorial Countercurrent; NEC: North Equatorial Current; SEC: South Equatorial Current; MC: Mindanao Current; HE: Halmahera Eddy; ME: Mindanao Eddy; NGCC: New Guinea Coastal Current; EAC: East Australian Current

ward at similar speeds (Kuroda 2000). However, this reversal does not always happen. In particular, Ueki et al. (2003) observed that the NGCC did not reverse at all during the 1997-1998 El Niño event. Further south, the model also correctly features the turbulent southward-flowing East Australian Current (EAC), which is part of the western boundary current system of the South Pacific subtropical gyre (Bowen et al. 2005).

The Indonesian Throughflow (ITF), which is the broad flow of Pacific waters into the Indian Ocean through the Indonesian archipelago, is another main circulation feature of the studied area. The volume transport of the simulated ITF is close to $9 \mathrm{~Sv}$, flowing mostly through the Makassar Strait, with secondary pathways to the east, between Sulawesi and New Guinea, consistent with observations (e.g. Gordon 2005). The ITF exits the Indonesian archipelago through 3 main passages: the Lombok Strait, the Ombai Strait and the Timor Passage, as observed (At- madipoera et al. 2009). The outflowing water mostly augments the Indian Ocean South Equatorial Current (Indian SEC), also in agreement with observations (Wijffels et al. 2008).

\section{Simulating trajectories}

Pure drift trajectories induced by the G1-simulated currents were computed using the Lagrangian trajectory code ARIANE. This freely available software (www.univ-brest.fr/lpo/ariane/) uses an accurate, quasi-analytical, solution of the advection equation (Blanke \& Raynaud 1997). Daily averaged values of the current in the first model layer (0 to $1 \mathrm{~m}$ ) were employed in all drift simulations. One position per day was stored for further analysis.

To analyze the initial pathways of hatchlings' dispersal and their interannual variability we first per- 
formed a set of six $1 \mathrm{yr}$ long simulations of the passive drift of 1000 hatchlings released off Jamursba-Medi $(\mathrm{n}=500)$ and Kamiali $(\mathrm{n}=500)$. For the 6 nesting seasons from 2002 to 2007, the drift of each hatchling was simulated over $365 \mathrm{~d}$ from its date of release.

We then performed a $6 \mathrm{yr}$ long simulation of the purely passive drift of 10000 hatchlings released, during the 2002 nesting season only, from JamursbaMedi $(\mathrm{n}=5000)$ and Kamiali $(\mathrm{n}=5000)$. This is the longest possible drift simulation achievable with the G1 current data set.

As mentioned above, the passive drift hypothesis becomes questionable in such a long simulation. In an attempt to obtain a more realistic, albeit incomplete, description of juveniles' movements we performed a second 6 yr long simulation no longer neglecting the juveniles' swimming activity but assuming it is limited to random movements, mimicking motions targeted at randomly encountered drifting prey (Witherington 2002). In practice, such movements are added to passive drift movements (still simulated by ARIANE) by displacing the position of the drifting particles at the end of each (daily) time step by a distance $d$ in a randomly chosen direction $D$. A similar technique was recently used by Scott et al. (2012) to simulate the impact of a directed swimming activity, governed by magnetic cues (Lohmann et al. 2001), on the drift patterns of North Atlantic loggerhead turtle hatchlings. In our case, simulated swimming movements are random so that the distribution of $D$ is uniform between 0 and $360^{\circ}$. To simulate increased activity with age (a), the distance swum per day $(d)$ is assumed to increase linearly with the straight carapace length (SCL):

$$
d=\alpha \operatorname{SCL}(a)
$$

where SCL is estimated as a function of age following the von Bertalanffy growth curve fitted for leatherbacks by Jones et al. (2011):

$$
\operatorname{SCL}(a)=1.43\left[1-\mathrm{e}^{-0.226(a+0.17)}\right]
$$

In these equations, SCL and $d$ are in meters and $a$ is in years. In practice, we use $\alpha=3.5 \times 10^{4}$ so that $d=$ $50 \mathrm{~km} \mathrm{~d}^{-1}$ for adults having reached their maximum size ( $(\mathrm{SCL}=1.43 \mathrm{~m})$ according to Eq. (2). Such large daily movements are more typical of travelling than of foraging activity (Fossette et al. 2010a), but this choice of $\alpha$ was made to obtain an upper bound on the possible effect of random swimming on simulated dispersal patterns. According to Eqs. (1) \& (2), 1 yr old simulated individuals have a SCL of $0.33 \mathrm{~m}$ and swim $11.5 \mathrm{~km} \mathrm{~d}^{-1}$, while $6 \mathrm{yr}$ old individuals have a SCL of $1.07 \mathrm{~m}$ and swim $37.5 \mathrm{~km} \mathrm{~d}^{-1}$.

\section{Temperature and foraging habitats along simulated trajectories}

To characterize the thermal and foraging habitats encountered by juveniles, we estimated water temperature $\left(T_{\mathrm{w}}\right)$ and net primary production (NPP) along all simulated trajectories. Use of the NPP as a proxy for juveniles' food abundance is warranted since sea turtles generally forage at low trophic levels (Polovina et al. 2001, Saba et al. 2008), even if leatherbacks likely have a more specialized diet and essentially feed on gelatinous zooplankton whose abundance is not solely related to NPP (Lilley et al. 2011).

Satellite-derived estimates of NPP can be obtained from the Ocean Productivity web site (www.science. oregonstate.edu/ocean.productivity/). This standard NPP product is based on the vertically generalized production model (VGPM) of Behrenfeld \& Falkowski (1997). It is available for the entire 2002 to 2008 period, with a temporal resolution of $8 \mathrm{~d}$ and a horizontal resolution of $1 / 6^{\circ} . T_{\mathrm{w}}$ is taken to be the water temperature in the first layer ( 0 to $1 \mathrm{~m}$ ) of the G1 model. As G1 assimilates satellite-derived seasurface temperatures, $T_{\mathrm{w}}$ is within $0.5^{\circ} \mathrm{C}$ of these temperature observations. Based on these gridded data fields, we used simple linear interpolation in time and bilinear interpolation in space to estimate $T_{\mathrm{w}}$ and NPP values at each simulated (daily) turtle position.

\section{Hatchling release}

Given the marked seasonal variability of the regional surface currents, the timing of hatchling releases is important. The nesting season at Jamursba-Medi extends from April to September, peaking in July (Hitipeuw et al. 2007). In Kamiali, the nesting season is from November to March, peaking in December to January (Benson et al. 2007b, Dutton et al. 2007).

Allowing for an incubation period of about $2 \mathrm{mo}$, our simulated hatchling release period was between June and November, peaking in mid-September for Jamursba-Medi, and between January and May, peaking 1 March for Kamiali. Hatchlings were released daily. We arbitrarily chose the number of hatchlings released in each simulation (see 'Materials and methods: Simulating trajectories') but set the number of releases per day to fit a truncated normal distribution that peaked at the dates mentioned above (Fig. 3). 


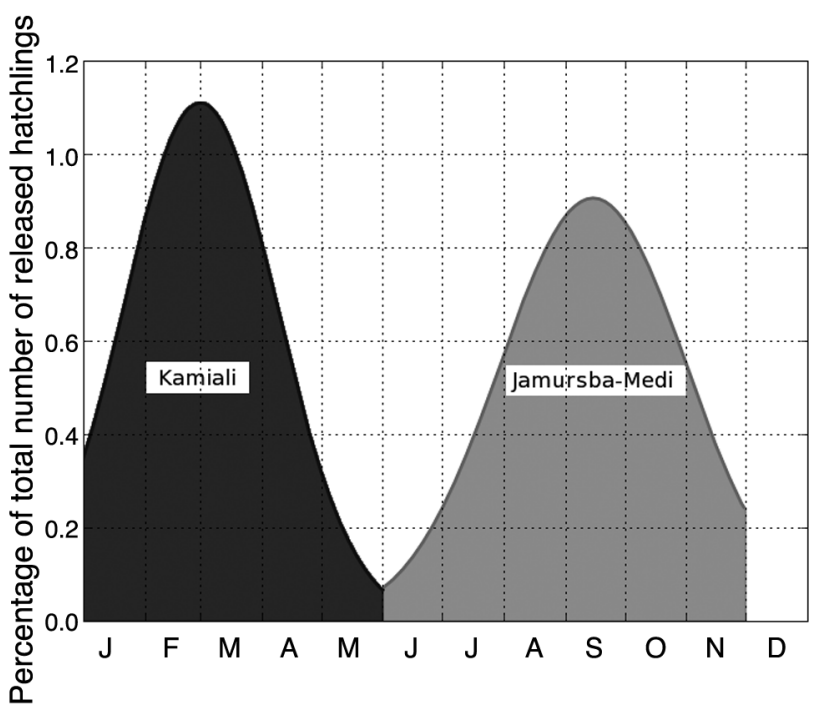

Fig. 3. Dermochelys coriacea. Normalized distribution of the number of simulated hatchlings released every day from Kamiali and Jamursba-Medi

To simulate the effect of the swimming frenzy, hatchlings were released in a $0.25^{\circ} \times 0.25^{\circ}$ area centered about $40 \mathrm{~km}$ off their nesting beach. The release positions were randomly chosen but uniformly distributed inside this area. The observed swimming speed of leatherback hatchlings is close to $1 \mathrm{~km} \mathrm{~h}^{-1}$ during the swimming frenzy (Davenport 1987, Wyneken 1997). Hatchlings should thus be able to reach the release area during their first $24 \mathrm{~h}$ of frenzy and then actively disperse in this area within the next few days, when their swimming activity becomes mainly limited to daylight hours (Wyneken \& Salmon 1992).

\section{RESULTS}

\section{Annual simulations}

Results of our 1 yr simulations reveal that oceanic variability off New Guinea generates multiple dispersal patterns (Fig. 4) as hatchlings emerging from the same beach, but on different days, are entrained by currents in different directions. Hatchlings emerging from Jamursba-Medi and Kamiali can, within a few months, reach 4 very different oceanic areas (Fig. 5): the Indonesian Seas and South China Sea (hereafter referred to as IC), the North Pacific (NP), the South Pacific (SP) and the Indian Ocean (IO). In addition, simulations show that complex regional current systems offer multiple pathways between the nesting beaches and these 4 oceanic areas.

\section{Oceanic pathways from Jamursba-Medi}

Most simulated hatchlings emerging from JamursbaMedi initiate their oceanic journey moving westward under the influence of the NGCC and SEC (Fig. 4a). Having reached the western tip of New Guinea they can then follow 2 main pathways. The first follows secondary branches of the ITF and rapidly leads hatchlings into the Indonesian seas through various passages between Sulawesi and New Guinea. The second pathway leads hatchlings northwestward around the anticylonic HE. From there, several drift patterns are possible. Some turtles leave the HE moving east into the narrow NECC, until shearinduced lateral mixing finally entrains them into the NEC, that is back westward into the clockwise circulation of the North Pacific subtropical gyre. Some can drift as far as $170^{\circ} \mathrm{W}$ before getting entrained into the gyre. A very small number of hatchlings having followed the same route into the NECC get entrained into the SEC and end up in the South Pacific. Other turtles leave the $\mathrm{HE}$ to circulate anti-clockwise around the ME. Upon reaching the northwestern flank of this eddy, some are transported further north by the powerful Kuroshio and reach Japan within a year. Others get entrained into the MC that leads them back into the IC area and the Makassar Strait following the main branch of the ITF.

Once in the IC area turtles move through the maze of the Indonesian archipelago before being transported out into the Indian Ocean, mostly through the Lombok Strait, the Ombai Strait, or the Timor Passage. From there they are entrained into the South Indian Ocean subtropical gyre and start flowing westward with the Indian SEC (Fig. 4a).

\section{Oceanic pathways from Kamiali}

Kamiali hatchlings also drift into the 4 previously mentioned oceanic areas (Fig. 4b), but their distribution is slightly different and largely controlled by the seasonally variable NGCC. Depending on the NGCC direction at the time of emergence (Table 1), Kamiali hatchlings are transported either southward into the SP or northward along the northern coast of New Guinea and into the NP. All hatchlings sent adrift along the northern coast of the New Guinea coast pass off Jamursba-Medi from where they can follow the oceanic routes described in the previous section and drift into the NP, IC and IO areas. Because of the seasonal current variability, their distribution between these different routes differs from that of the 

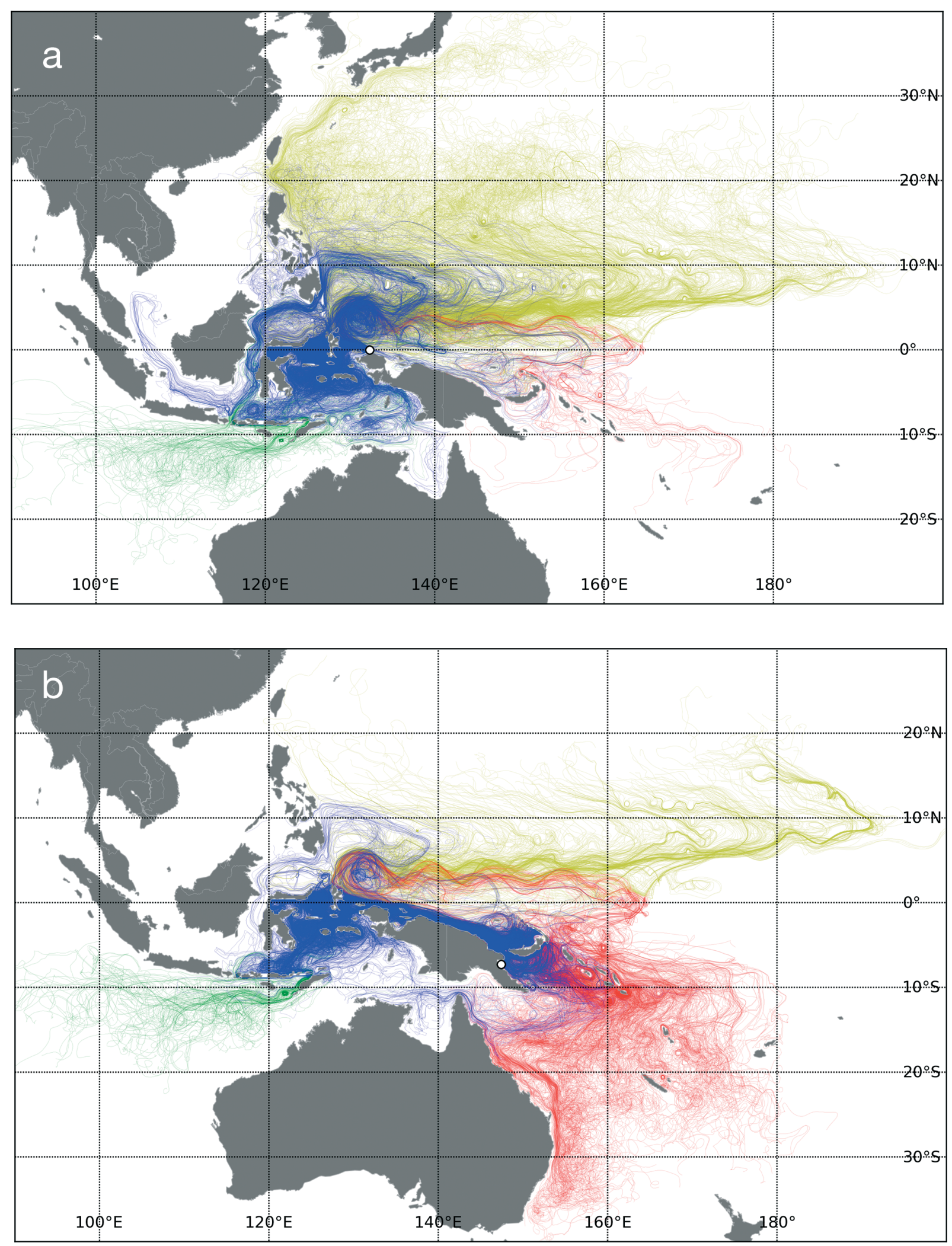

Fig. 4. Dermochelys coriacea. One year long trajectories of hatchlings released from (a) Jamursba-Medi and (b) Kamiali beaches. The color of each track depends on the location of its end point (see Fig. 5) 


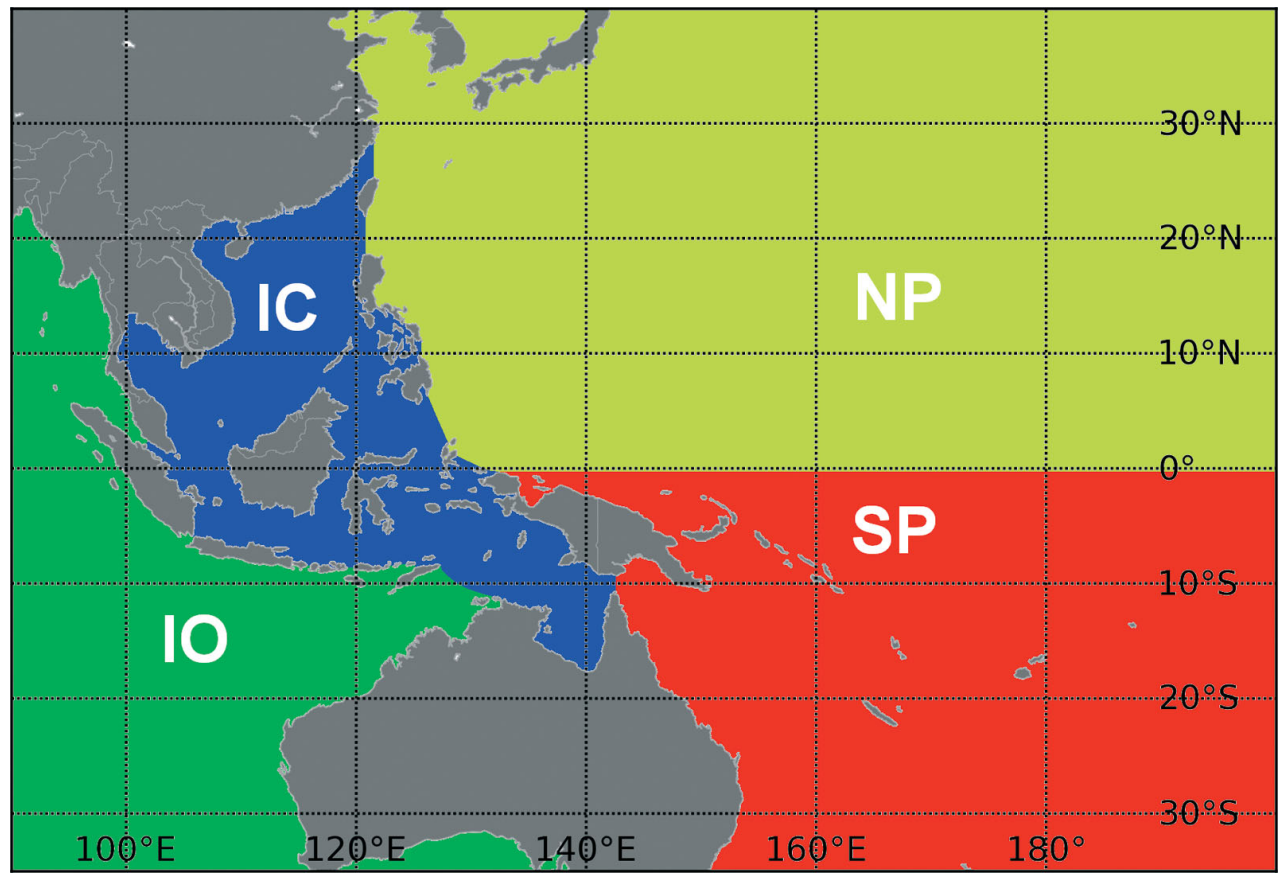

Fig. 5. Geographic extent of the 4 oceanic areas reached by simulated hatchlings. IC: Indonesian seas and China Sea, NP: North Pacific, SP: South Pacific, IO: Indian Ocean

Jamursba-Medi hatchlings. For example, several Kamiali hatchlings circle around the HE, flow into the NECC and then recirculate southward into the SEC. This pathway is used by very few JamursbaMedi hatchlings (Fig. 4a,b).

Kamiali hatchlings transported south of $10^{\circ} \mathrm{S}$ are dispersed broadly southward by the complex and highly variable current system of the southwest subtropical Pacific Ocean (e.g. Kessler \& Gourdeau 2007). A few (on average $2.5 \%$ of all simulated hatchlings) enter the IC area through the Torres Strait, pushed by the weak westward currents that prevail during the southeast trade wind season (Wolanski et al. 1988). Many others get entrained into the EAC as they approach the Great Barrier Reef and then into the South Pacific subtropical gyre.

Table 1. Calendar of New Guinea Coastal Current (NGCC) reversal and monsoonal wind changes together with nesting and emergence periods in Kamiali $(\mathrm{K})$ and Jamursba-Medi (JM). Arrows: direction of NGCC flows. Dotted arrows: current is not always present

\begin{tabular}{|c|c|c|c|c|c|c|c|c|c|c|c|c|}
\hline & J & $\mathbf{F}$ & $\mathbf{M}$ & A & $\mathbf{M}$ & J & J & A & $\mathbf{S}$ & 0 & $\mathbf{N}$ & D \\
\hline Monsoonal winds & NW & NW & NW & & SE & SE & SE & SE & SE & & NW & NW \\
\hline NGCC & $" \bullet$ & $\because$ & 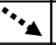 & & $\mathbf{K}$ & & & $\mathbf{k}$ & $\bar{B}$ & & $\because$ & $" 4$ \\
\hline Nesting & $\mathrm{K}$ & $K$ & $K$ & $\mathrm{JM}$ & JM & $\mathrm{JM}$ & JM & $\mathbf{J M}$ & JM & & $\mathbf{K}$ & K \\
\hline Hatchling emergence & K & K & $\mathbf{K}$ & $\mathbf{K}$ & $\mathbf{K}$ & $\mathbf{J M}$ & $\mathbf{J M}$ & $\mathbf{J M}$ & $\mathbf{J M}$ & $\mathrm{JM}$ & $\mathrm{JM}$ & \\
\hline
\end{tabular}

Main dispersal schemes and variability

Dispersal schemes from the nesting beaches into the different oceanic basins are not only spatially complex, they are also highly variable. We found a large interannual variation in the number of hatchlings present in each oceanic area at the end of each simulated year, with numbers typically varying by factor of 3 to 4 (Table 2).

On average about half of Jamursba-Medi and Kamiali hatchlings end up in the IC area despite the fact that these 2 beaches are not situated there. This highlights the importance of the NGCC current, which entrains hatchlings from both nesting beaches towards the northwestern end of New Guinea from where the ITF then pushes them into the IC area. Since hatchlings in the IC area almost inevitably end up in the Indian Ocean, our results point to 3 main dispersal patterns from Kamiali (into IC-IO, SP and NP) and 2 from Jamursba-Medi (into IC-IO and NP). Dispersal from Jamursba-Medi into SP is not significant.

Year 2002 is of special interest since it is the starting point for the $6 \mathrm{yr}$ simulations and coincidentally is the only departure year for which a significant number of 
Table 2. Dermochelys coriacea. Number of simulated hatchlings from Jamursba-Medi and Kamiali present in each oceanic area (IC, NP, SP, IO, see Fig. 5) at the end of each simulated year

\begin{tabular}{|lcccccccccc|}
\hline \multirow{2}{*}{ Area } & \multicolumn{1}{c}{ Year } & & & Minimum & Mean \\
& \cline { 2 - 7 } & 2002 & 2003 & 2004 & 2005 & 2006 & 2007 & $\begin{array}{c}\text { Maximum } \\
(\%)\end{array}$ \\
\hline \multicolumn{2}{l}{ Jamursba-Medi } \\
IC & 161 & 204 & 211 & 395 & 297 & 391 & 32.2 & 55.3 & 79.0 \\
NP & 280 & 270 & 264 & 73 & 148 & 67 & 13.4 & 36.7 & 56.0 \\
SP & 40 & 1 & 0 & 2 & 2 & 1 & 0.0 & 1.5 & 8.0 \\
IO & 19 & 25 & 25 & 30 & 53 & 41 & 3.8 & 6.5 & 10.6 \\
Kamiali & & & & & & & & \\
IC & 235 & 299 & 117 & 343 & 214 & 268 & 23.4 & 49.2 & 68.6 \\
NP & 134 & 61 & 208 & 49 & 55 & 46 & 9.2 & 18.4 & 41.6 \\
SP & 111 & 47 & 169 & 100 & 228 & 167 & 9.4 & 27.4 & 45.6 \\
IO & 20 & 93 & 6 & 8 & 3 & 19 & 0.6 & 5.0 & 18.6 \\
\hline
\end{tabular}

Jamursba-Medi hatchlings reach the SP (Table 2). This must be kept in mind and might be related to the fact that 2002 is classified as a moderate El Niño year (www.cpc.ncep.noaa.gov/products/analysis monitoring/ensostuff/ensoyears.shtml). This is, however, difficult to ascertain as the G1 reanalysis does not contain any major El Niño event. In addition, the weak El Niño events of 2004 and 2006 are obviously not associated with an increased number of Jamursba-Medi hatchlings drifting into the SP (Table 2).

\section{Six year simulations}

Passive drift simulation

Results of our 6 yr passive drift simulation confirm that the Indonesian seas are only a transit area through which simulated hatchlings released in 2002 from Jamursba-Medi and Kamiali drift into the Indian Ocean (Fig. 6). Very few simulated individuals older than 1 to 2 yr are seen in this area, with the noticeable exception of Tomini Bay (Sulawesi), where a large number of turtles are still found after several years of simulation. In fact, most individuals entering this bay become trapped and circulate there for several months to several years. This is likely an artifact of the G1 model in which horizontal resolution $\left(0.25^{\circ} \times\right.$ $0.25^{\circ}$ ) is insufficient to properly simulate the circulation in the narrow semi-enclosed Tomini Bay. The only noteworthy effect of this model shortcoming is to artificially diminish the number of simulated juveniles finally reaching the IO.

Simulated dispersal of juveniles beyond first year appears to be confined to the interior of the 3 subtropical gyres (NP, SP and IO) within which hatch-
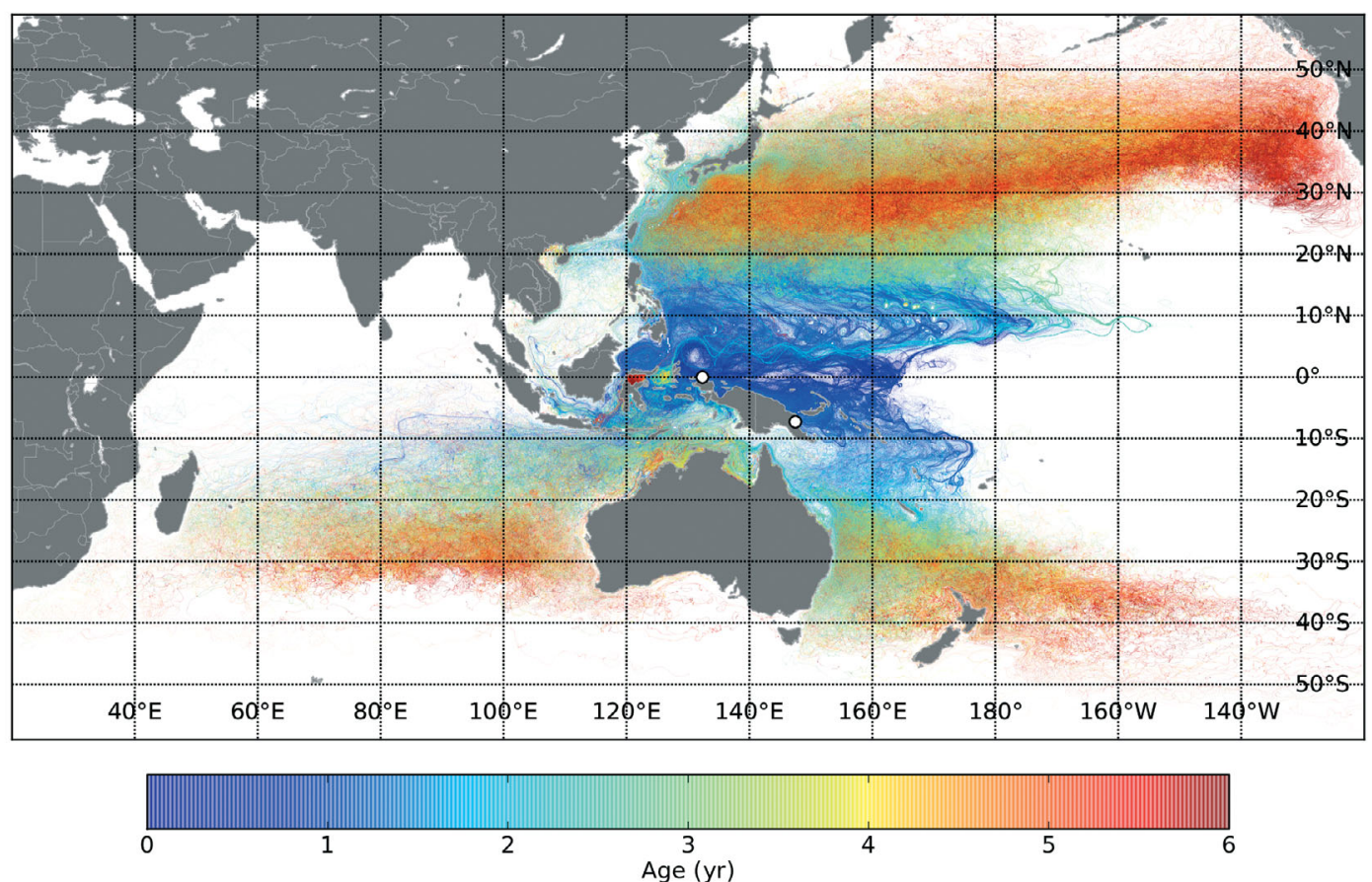

Fig. 6. Dermochelys coriacea. Six year long passive drift trajectories of hatchlings released during the 2002 nesting season from both Jamursba-Medi and Kamiali (white dots, see Fig. 1). The color along each track evolves as a function of the age of the simulated turtle 

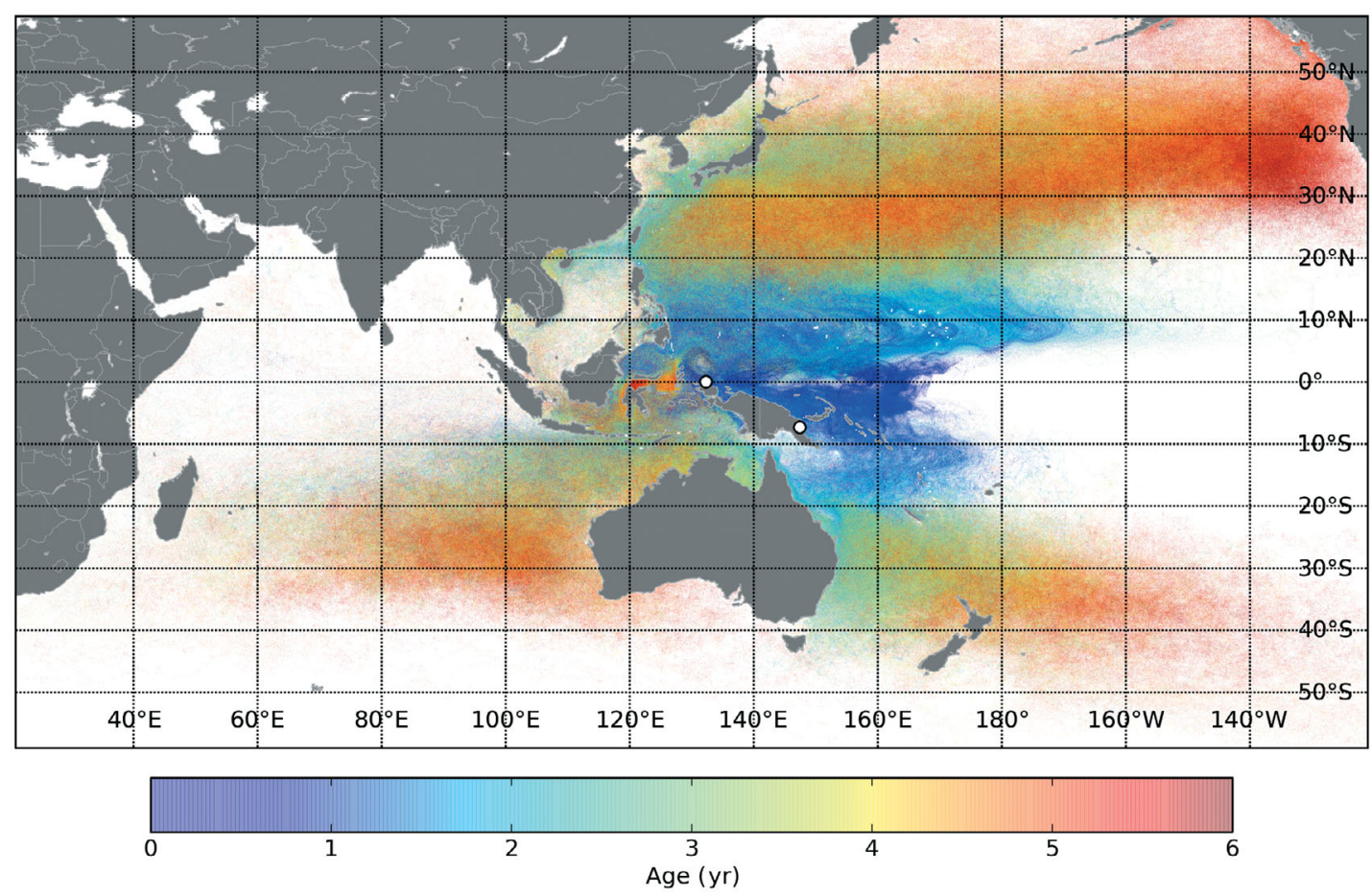

Fig. 7. Dermochelys coriacea. As in Fig. 6, but with random movements added to passive drift

lings are injected. Drift movements are markedly different within these 3 gyres. Individuals circulating in the strong NP subtropical gyre move rapidly eastward and reach the United States Pacific coast around $40^{\circ} \mathrm{N}$ within $5 \mathrm{yr}$. The fastest ones are found drifting southward in the California current during the last year of simulation (Fig. 6). Hatchlings entrained in the less developed SP gyre do not move as far east as the NP hatchlings. Most recirculate northward (and then westward) before reaching $140^{\circ} \mathrm{W}$. Only a dozen (out of $10000 \mathrm{simu}$ lated individuals) drift east of $140^{\circ} \mathrm{W}$, pushed by a rather weak South Pacific current (Stramma et al. 1995). The situation is different in the South Indian Ocean as juveniles are injected on the eastern side of the basin from where they are rapidly entrained westward by the broad Indian SEC. This current takes some of them as far as the east coast of Madagascar. However, most individuals leave the SEC and recirculate eastward well before reaching Madagascar. This recirculation keeps them well inside the subtropical gyre so that very few juveniles reach the subtropical front bordering the gyre below $40^{\circ} \mathrm{S}$ (Stramma \& Lutjeharms 1997). During the last simulated year, some individuals end up off Cape Leeuwin and along the southwestern coast of Australia after short loops inside the subtropical gyre.
Simulation with passive drift plus random swimming activity

Fig. 7 shows the simulated juveniles' dispersal patterns when random swimming activity, parameterized following Eq. (1), is added to passive drift. Despite the fact that the added swimming movements likely overestimate the actual juveniles' movements, the simulated dispersal patterns do not differ significantly from those obtained with strictly passive drift (Fig. 6). Dispersal pathways remain essentially the same, and dispersal areas are only broadened by added diffusion, as expected. This clearly indicates that, even in the presence of significant random swimming activity, juveniles' dispersal remains largely shaped by oceanic currents, as commonly observed in various juvenile dispersal studies (e.g. Carreras et al. 2006, Blumenthal et al. 2009).

\section{Primary production along trajectories}

NPP sampled along simulated pure-drift trajectories shows that juveniles encounter widely different foraging habitats (Fig. 8). In the NP, juveniles would encounter highly productive areas along the Asiatic continental margin, in the Japan Sea, inside the Northern Pacific Transition Zone (NPTZ, typically 

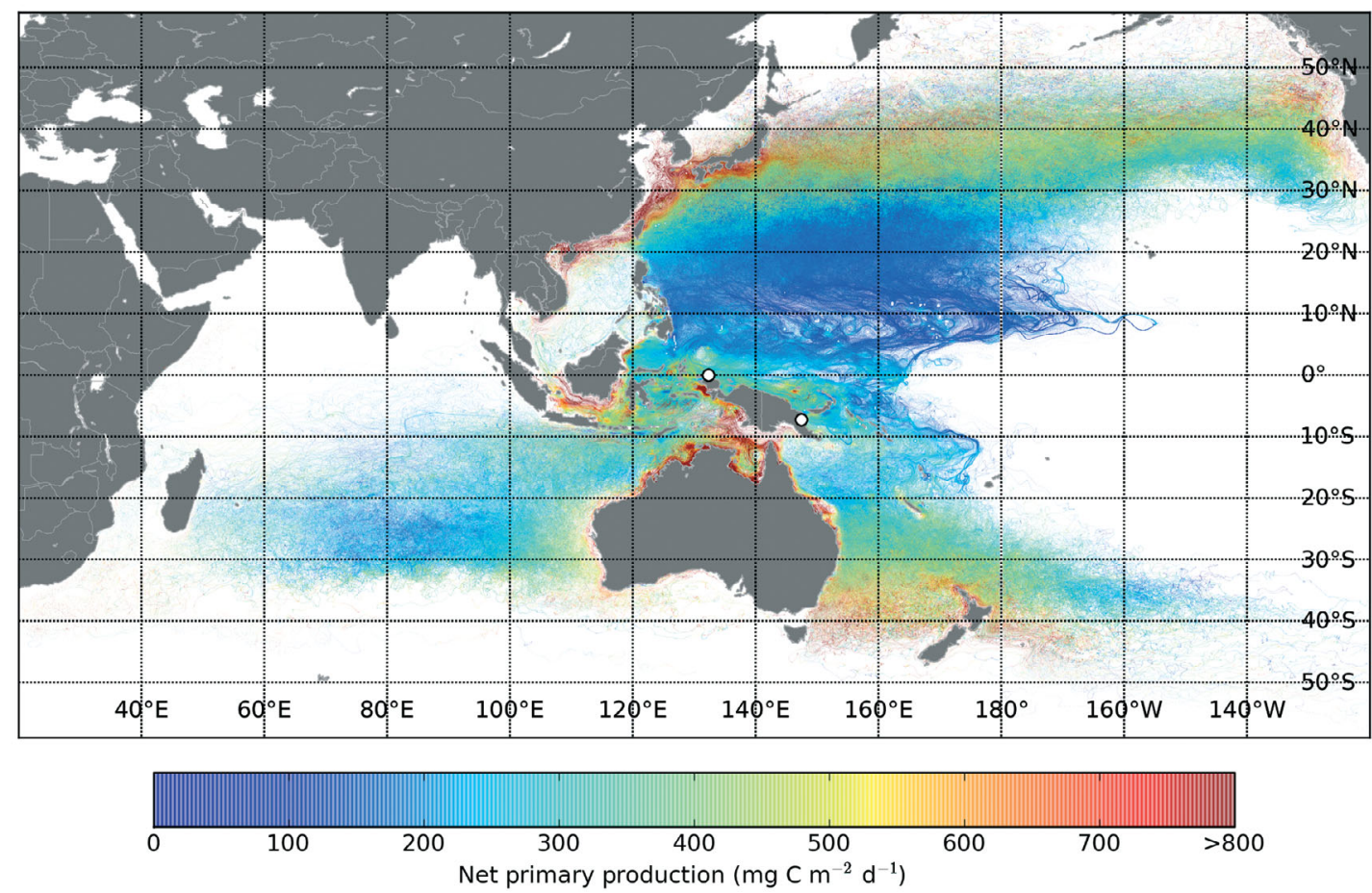

Fig. 8. Net primary production estimated along all 6 yr long passive drift trajectories

found between 30 and $40^{\circ} \mathrm{N}$ ), and finally along the coast of California and Oregon. The NPTZ, in particular, is known to provide very favorable foraging grounds to various marine predators, including sea turtles (Polovina et al. 2001). In the SP, juveniles disperse less widely and would encounter productive areas only in the western part of the basin: along the eastern coast of Australia, the Tasman and the southern subtropical front to about $10^{\circ}$ east of New Zealand. Juveniles drifting in the IO are less favored. Some of them can drift into productive waters along the western coast of Australia, but unlike the juveniles circulating in the NP and SP, their drift trajectories maintain most of them in oligotrophic waters inside the gyre without providing the opportunity of encountering the more productive waters of the subtropical front lying south of their dispersal area. The situation is essentially the same when considering trajectories with added random movements.

\section{DISCUSSION}

\section{Basis for analyzing model results}

While Lagrangian drift simulations have been increasingly used to study juvenile sea turtle dispersal (e.g. Blumenthal et al. 2009, Hays et al. 2010,
Scott et al. 2012), the validation of modeling results remains challenging due to the scarcity of direct observations of hatchlings and juveniles at sea, especially for leatherbacks Dermochelys coriacea. Fortunately, leatherback bycatch data (provided by the NOAA Fisheries, Pacific Islands Regional Observer Program, Hawaii), including observed interactions with juveniles, were available to ground truth our model results. The results from satellite telemetry and genetic studies also provide useful information to further inform drift simulations (Dutton 2007, Godley et al. 2010). In particular, Hays et al. (2010) first observed a close coincidence between simulated juvenile dispersal patterns and the location of foraging grounds of satellite-tracked adults in a population of loggerhead turtles nesting in the eastern Mediterranean Sea. This led the authors to hypothesize that foraging sites used by sea turtles reflect their previous experiences as hatchlings and young juveniles, a hypothesis also evoked by Fossette et al. (2010b) to explain the observed foraging ground distribution of leatherbacks in the North Atlantic. This idea can actually be traced back to earlier works of Lohmann et al. (1999, 2008) and Freake et al. (2006) who proposed that sea turtles might progressively develop a magnetic map of the oceanic areas visited for use later in life, based on their ability to detect variations in the Earth's magnetic field (Lohmann \& 
Lohmann 1994, 1996). In particular, hatchlings might imprint on the magnetic characteristics of their natal area to later direct natal homing, and juveniles might record the magnetic positions of randomly discovered foraging areas to return to such sites after reproductive migrations. Natal homing in sea turtles is now generally accepted and supported by a growing body of genetic evidence (Meylan et al. 1990, Bowen \& Karl 1996, Dutton et al. 2005). That juveniles record the positions of encountered foraging grounds and re-use them as adults is also a reasonable hypothesis which we term the learned migration goal (LMG) hypothesis. There would certainly be selective pressure to evolve the behavior of targeting previously known foraging areas instead of wandering in search of other unknown feeding grounds as this likely maximizes chances of survival. Note that the targeted migration goal might be a broad pelagic foraging area, at the scale of a large marine ecosystem (LME), as is the case for leatherbacks (Benson et al. 2011), or a more restricted neritic area for species like loggerheads, which recruit as juveniles to such foraging sites. In both cases, the LMG hypothesis is consistent with the observation that adult sea turtles swim fairly direct routes between their distant breeding and feeding areas (e.g. Papi et al. 1995, Luschi et al. 1998, Ferraroli et al. 2004), indicating that they have knowledge of where they are going. It is also consistent with the foraging ground fidelity observed in various sea turtle populations (Limpus et al. 1992, Broderick et al. 2007, Schofield et al. 2010), including leatherbacks (James et al. 2005, Fossette et al. 2010b, Benson et al. 2011).

\section{Juvenile dispersal and adult migration range in the Pacific}

Our simulations reveal a rare situation in which hatchlings from the same nesting stock are led by oceanic currents in 3 totally different oceanic basins and disperse quite differently within these basins (Fig. 6): dispersal covers the whole longitudinal extent of the NP, remains limited to the western part of the $\mathrm{SP}$, and is restricted to the tropical band (down to about $30^{\circ} \mathrm{S}$ ) in the South IO. In the Pacific, productive areas visited by simulated juveniles (Fig. 8) appear to coincide with the foraging areas actually used by adults. Multiple observations demonstrate that adult western Pacific leatherbacks indeed exploit the entire North Pacific. They are commonly observed foraging offshore California during summer and fall (Benson et al. 2007c) and are inciden- tally caught by longline and driftnet fisheries operating in the central and eastern part of the NPTZ. Genetic analyses of individuals caught at sea or found stranded in California confirm that they are almost exclusively from the western Pacific stock (Dutton et al. 2000). Furthermore, satellite tracking of 37 female leatherbacks nesting in Jamursba-Medi (Benson et al. 2011) revealed that they all target foraging grounds situated in the NP basin and adjacent seas, from the Sulu and Japan Seas in the west to the United States Pacific coast in the east. All these adult foraging grounds are commonly visited by simulated, freely drifting, juveniles (Fig. 8), with the only exception being the Sulu Sea and the adjacent southern part of the South China Sea. This area is visited by only $2 \%$ of the simulated Jamursba-Medi juveniles, while it was actually exploited by 13 out of 37 adults tracked by Benson et al. (2011). However, the Sulu Sea is separated from much more frequented areas of the North Pacific and Sulawesi Sea by the complex Philippine and Sulu archipelagos, and horizontal resolution of the G1 model only allows a crude and incomplete representation of the many small passages that exist throughout these archipelagos. This likely reduces the simulated exchange of waters, and thus of juveniles, between the Sulu and South China Seas, and the more densely populated adjacent seas. A higher resolution ocean model would be better suited to investigate this further.

Leatherbacks' dispersal is clearly more limited in the South Pacific. Adult leatherbacks are commonly observed along the east coast of Australia (Limpus 2009). Occasional sightings are also reported off New Zealand, mostly during summer around the North Island (Gill 1997). In addition, all 17 females tracked from Kamiali and the neighboring beach of Maus Buang in the Huon Gulf (Benson et al. 2011) migrated exclusively into the southwestern Pacific. All recorded trajectories occur within a narrow angular sector, aiming at the productive waters of the east coast of Australia, the Tasman front, and the western end of the southern subtropical front. This dispersal pattern is remarkably similar to that of the simulated juveniles.

Altogether, these observations clearly support the LMG hypothesis, even if it remains possible that directed swimming towards foraging sites and fidelity to these sites might not be learned but inherited, as is the case in various birds (e.g. Berthold \& Helbig 1992). However, this innate migration direction (IMD) hypothesis is less appealing since: (1) assuming inheritance is less parsimonious than assuming learning, particularly given the observed 
diversity of foraging destinations; (2) it is difficult to conceive why sea turtles, having gained extensive knowledge of an oceanic area as juveniles, would, as adults, choose to migrate in an innate direction instead of in a familiar direction; and (3) the IMD hypothesis provides no explanation for the observation that leatherbacks migrating towards the North Pacific leave their breeding area in a very broad range of directions, while those migrating in the South Pacific migrate in a much narrower angular sector.

The LMG hypothesis implies a strong correlation between juvenile dispersal areas and adult migration goals. Though clearly observed in the Pacific, this correlation must be questioned on (at least) 2 points:

(1) Our model predicts important juvenile dispersal from Kamiali into the NP, and from both Kamiali and Jamursba-Medi into the IC-IO area. However, none of these dispersal patterns is observed in tracked adults. Does this contradict the LMG hypothesis?

(2) Our model simulates juvenile dispersal assuming either pure passive drift or drift plus random movements. While this assumption is likely valid during the first period of life, it might no longer apply to larger juveniles for which swimming activity might induce significant deviations from simple drift trajectories. If so, do the actual juvenile trajectories still lead them towards the same productive areas and thereby maintain the correlation observed in the Pacific between juvenile dispersal areas and adult migration goals?

\section{Missing dispersal patterns}

Even if the LMG hypothesis implies that adults target migration goals that they previously visited as juveniles, one would not expect all simulated juvenile drift patterns to be exploited by adults. Indeed, the oceanic circulation can lead hatchlings into unfavorable areas where mortality is so high that few or no individuals survive and later return to their breeding area. Adult migrations may thus represent only a subset of successful juvenile drift scenarios (Hays et al. 2010).

Our simulations show that over half the JamursbaMedi and Kamiali hatchlings drift into the IC-IO area, while, so far, no adult has been tracked in that direction. Can we thus conclude that this drift pattern comes with little or no chances of survival? The answer is probably yes, for several reasons. Simulated Jamursba-Medi hatchlings cross the Indonesian archipelago in about 8 mo (mean age of the sim- ulated Jamursba-Medi hatchlings when they reach the $\mathrm{IO}=240 \mathrm{~d}, \mathrm{SD}=66 \mathrm{~d}$ ). During that period, they drift through rich coastal waters where upper predators abound and where fisheries-induced mortality is likely high. Indonesia is, indeed, home to $>2.2$ million fishermen who exploit a large, mostly artisanal, fishing fleet, including an important shrimping fleet (FAO 2009). Heavily-used surface nets would be most detrimental to post-hatchlings with limited diving abilities. Then, juveniles having survived the crossing of the Indonesian seas will enter the IO close to the equator. They will drift into the South Indian subtropical gyre but without reaching the most productive waters found near its southern boundary (Fig. 8). This developmental habitat might be less favorable than that encountered by juveniles drifting in the NP or SP where currents lead them towards the productive waters of the subtropical fronts. Natural mortality in the IO might thus be higher than in the Pacific. Finally, juveniles having survived until the age of maturity will face the challenge of swimming back to their natal beach through the heavily fished Indonesian Seas. These, now larger, individuals are prone to incidental capture by many types of fishing gear including longlines (Gilman et al. 2009, Jones et al. 2011). Unfortunately, with an estimated effort of $>15$ million hooks per year and per $5^{\circ} \times 5^{\circ}$ area, the broad region between Indonesia and the Philippines is one of the most active longline fishing areas in the world (Lewison et al. 2004). In addition, the journey back to Jamursba-Medi is against the ITF. The different branches of this broad throughflow have velocities of 10 s of centimeters per second up to $1 \mathrm{~m} \mathrm{~s}^{-1}$ or more in the main Indonesian straits such as the Makassar, Lombok, or Ombai Straits (e.g. Chong et al. 2000, Sprintall et al. 2009). As adult leatherbacks travel at a typical swimming speed of 0.4 to 0.6 $\mathrm{m} \mathrm{s}^{-1}$ (Eckert 2006, Fossette et al. 2010a), individuals attempting to return to their natal beach would often be slowed, stopped, or even moved backwards by the currents, making the trip particularly challenging. Adverse currents would also lengthen the time spent in this active longline fishing area, thereby increasing the probability of incidental capture. All together, this makes it unlikely that Jamursba-Medi hatchlings ever return to their natal area once they drift into the IO. Kamiali hatchlings transported into the NGCC before entering the IC area would also meet the same fate as they follow the same trajectory into the IO. In both cases, hatchlings drifting into the IO would have a much smaller probability of survival and return than hatchlings directly drifting into the pelagic waters of the North or South Pacific Ocean. This may 
explain why adults tracked from Jamursba-Medi or Kamiali have never been observed to migrate into the IO. In addition, any adult migrating in this direction would also incur a higher probability of incidental capture. This would be an additional factor contributing to the final elimination of this dispersal scheme.

Similarly, none of the adults tracked so far from Kamiali migrate into the NP, while our simulations suggest that about $18 \%$ of the juveniles are sent adrift in that direction. Is the pathway from Kamiali into the NP also associated with very high mortality? Mortality inside the NP is probably not unusually high as many Jamursba-Medi hatchlings drift into this ocean, survive and are later tracked as adults migrating back into the NP. However, unlike Jamursba-Medi hatchlings, Kamiali hatchlings do not drift directly into the NP but have to undertake a $2000 \mathrm{~km}$ long journey drifting northwestward with the NGCC along the north coast of New Guinea before reaching the NP pelagic realm. This journey requires about 4 mo (mean age of passively drifting Kamiali hatchlings when crossing the JamursbaMedi meridian $=117 \mathrm{~d}$, SD $=52 \mathrm{~d}$ ) during which hatchlings mostly remain within 10s of kilometers from the coast. They thus travel in rich shelf waters and reef areas where natural predation is expected to be high and where interactions with artisanal fishing fleets are likely to occur. In addition, increased fisheries-induced mortality could impact older juveniles and adults that might be using the coastal NGCC pathway to and from the NP. The coastal leg of this dispersal pathway from Kamiali into the NP might thus be the most perilous part of the journey and reduce the survival rates to levels that preclude production of adults. A similar point was made by Saba et al. (2008) who speculated that coastal migrations are rarely observed in eastern Pacific leatherbacks because of high rates of juvenile and adult mortality induced by gillnet fisheries along the coastline of South and Central America. It is notable that out of the 5 juvenile dispersal patterns simulated here, only the 2 patterns with rapid access to the open ocean (Jamursba-Medi to NP and Kamiali to SP) appear to be re-used by adults. The 3 other juvenile dispersal patterns involve coastal legs and generally do not appear to be used by adults.

We must finally mention an additional possible, but highly hypothetic, explanation for the observation that, so far, no adult leatherback has been tracked from Kamiali into the NP. It is indeed possible that individuals, born in Kamiali and having circulated within the NP during their whole juvenile phase, have adapted to the northern hemisphere phenology where environmental cues would drive them to breed or nest during late boreal spring or summer. If their way back to Kamiali takes them first along the north coast of New Guinea anywhere near Bird's Head Peninsula, they will find themselves in the vicinity of major nesting beaches during the peak nesting season which might induce breeding in this area. The impetus to breed there might even be reinforced by the fact that the NGCC flows northwestward during that period and hence makes the eastward trip towards Kamiali particularly difficult. These individuals might then show fidelity to the site where they first bred or nested and keep foraging in the NP. In this case, they will never be seen again in Kamiali. This possibility is clearly speculative but is consistent with the high degree of genetic connectivity that has been observed between the Huon Gulf and Bird's Head nesting populations (Dutton et al. 2007), as well as the acknowledged flexibility of natal homing in leatherbacks on a broad regional scale (Dutton et al. 1999).

\section{The need to go beyond passive drift modeling}

The passive, or nearly passive, drift hypothesis is likely valid during the first months of a sea turtles' life. Differences between simulated and actual movements will thus initially be small but might later increase as individuals grow older and become more powerful swimmers.

Our simulations (Figs. $6 \&$ \&) show that strong regional currents rapidly disperse hatchlings emerging from Jamursba-Medi and Kamiali. Within a few months, up to a year, most of them are injected into the IO, NP, or SP subtropical gyres. Once there, they will progressively drift towards higher latitudes and encounter colder waters. Leatherbacks exhibit the widest thermal tolerance of all sea turtles. Various physiological and behavioral adaptations enable them to maintain a relatively high body temperature $\left(T_{\mathrm{b}}\right)$ in cold waters (e.g. Bostrom \& Jones 2007). However, the temperature gradient $\left(T_{\mathrm{b}}-T_{\mathrm{w}}\right)$ that can be achieved increases with size (Bostrom et al. 2010). Therefore, only large adults can exploit the coldest foraging areas, while smaller individuals remain limited to warmer waters. Accordingly, the size of leatherbacks observed at sea exhibits a clear gradient with temperature and latitude (Eckert 2002, Witt et al. 2007). Analysis of a limited set of juvenile leatherback sightings led Eckert (2002) to conclude that individuals with a curved carapace length (CCL) 


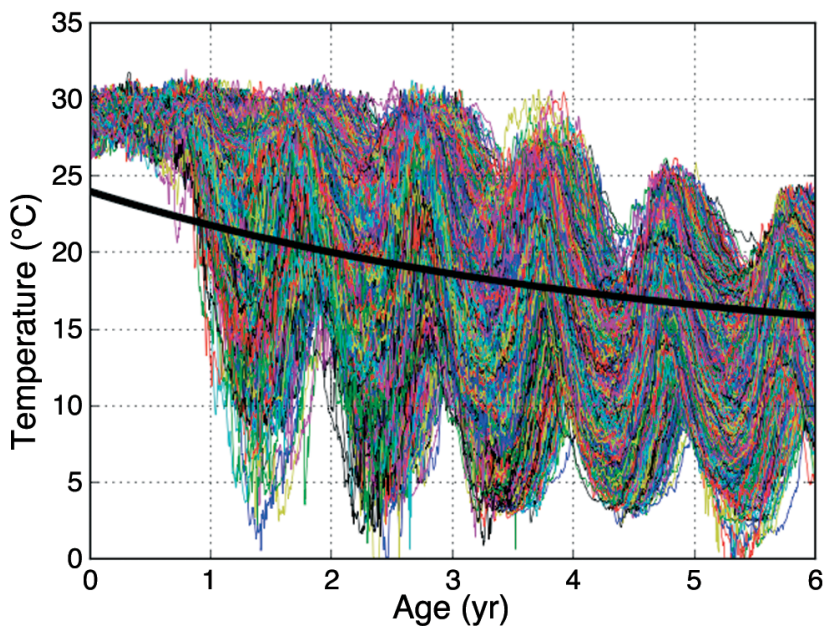

Fig. 9. Water temperature ( $T_{\mathrm{w}}$ ) encountered by the 1398 simulated Jamursba-Medi juvenile Dermochelys coriacea passively drifting towards the United States Pacific coast. The black continuous curve shows their estimated minimum sustainable temperature ( $\left.T_{\min }\right)$ as a function of age (Eq. 4$)$

$<1 \mathrm{~m}$ occur only in waters warmer than $26^{\circ} \mathrm{C}$. If this is the case, none of the 2 to 3 yr old juveniles that we simulate drifting north of $20^{\circ} \mathrm{N}$, or south of $20^{\circ} \mathrm{S}$, could survive at such latitudes where $T_{\mathrm{w}}$ is generally $<26^{\circ} \mathrm{C}$. More recently, however, 3 small $(63 \mathrm{~cm}<$ CCL $<85 \mathrm{~cm}$ ) leatherbacks were observed off Chile in waters between 18.1 and $21.9^{\circ} \mathrm{C}$ (Donoso \& Dutton 2010). These temperatures are well below $26^{\circ} \mathrm{C}$ but still above the temperatures that many of our 3 to $4 \mathrm{yr}$ old simulated juveniles encounter during winter poleward of $30^{\circ}$. This suggests that pure passive drift behavior cannot be maintained very long by juveniles which will be prompted to swim towards warmer waters as soon as currents transport them into areas where $T_{\mathrm{w}}$ drops below their preferred temperature and approaches their minimum tolerated temperature $\left(T_{\min }\right)$. To quantify the occurrence of such events, a precise estimate of $T_{\min }$ would be needed. This information is currently unavailable, but a crude estimate can be obtained assuming that: (1) $T_{\min }$ decreases linearly with size (SCL); (2) newborn leatherbacks can tolerate $T_{\min }=24^{\circ} \mathrm{C}$, the mean temperature at which Jones et al. (2011) raised hatchlings; and (3) the immature individual $(\mathrm{CCL}=85 \mathrm{~cm})$ observed by Donoso \& Dutton (2010) in water at a temperature of $18.1^{\circ} \mathrm{C}$ was close to its $T_{\min }$. It follows that:

$$
T_{\min }(\mathrm{SCL})=24.4-7.9 \cdot \mathrm{SCL}
$$

This relation is obtained knowing that the mean SCL of hatchlings $(a=0)$ is $5.4 \mathrm{~cm}$ (based on Eq. 2), and that $\mathrm{CCL}=85 \mathrm{~cm}$ corresponds to $\mathrm{SCL}=79.8 \mathrm{~cm}$, based on the relation $\mathrm{SCL}=(\mathrm{CCL}-0.0204) / 1.04$ (Tucker \& Frazer 1991). Interestingly, Eq. (3) yields $T_{\min }=13.1^{\circ} \mathrm{C}$ for adults having reached the maximum SCL of $1.43 \mathrm{~m}$ given by Eq. (2). McMahon \& Hays (2006) situate the lower bound on adult leatherbacks' thermal habitat at around $15^{\circ} \mathrm{C}$, while Witt et al. (2007) indicate a smaller value of 10 to $12^{\circ} \mathrm{C}$. Our $13.1^{\circ} \mathrm{C}$ estimate thus appears to be within the reasonable range of values. Using Eq. (2), $T_{\min }$ can readily be expressed as a function of age:

$$
T_{\min }(a)=13.1+11.3 \mathrm{e}^{-0.226(a+0.17)}
$$

Based on this relation we can easily determine when and where simulated juveniles encounter $T_{\mathrm{w}} \leq$ $T_{\min }$. The example of the Jamursba-Medi juveniles drifting towards California is especially interesting. The 6 yr long pure drift simulation yields 1398 individuals that move past $140^{\circ} \mathrm{W}$ in the North Pacific, and are thus headed towards the United States Pacific coast. As shown in Fig. 9, the water temperatures they encounter along their drift trajectories remain well above $T_{\min }$ during the first year of simulation, as currents keep them in warm, near-equatorial, areas. During the second year, $T_{\mathrm{w}}$ starts dropping seasonally below $T_{\min }$ and nearly 500 simulated juveniles $\left(35 \%\right.$ ) endure $T_{\mathrm{w}}<T_{\min }$, mostly individuals that drifted rapidly northward into the Kuroshio, without circulating first into the NECC. A year later, $<250$ individuals have not yet encountered $T_{\mathrm{w}}<T_{\min }$. At the end of the simulation, essentially all juveniles have endured at least 1 period with $T_{\mathrm{w}}<T_{\min }$. Fortunately, this result shows little sensitivity to our, admittedly crude, estimate of $T_{\min }$. Indeed, if $T_{\min }$ is lowered by as much as $5^{\circ} \mathrm{C}$ (for all ages), still $85 \%$ of the juveniles drifting towards California encounter water temperatures below their $T_{\min }$.

Seasonal migration towards warmer waters thus appears to be mandatory for the survival of juvenile leatherbacks in the North Pacific. Such migrations towards warmer waters are commonly observed in autumn in both juveniles and adults of other sea turtle populations (e.g. Musick \& Limpus 1997, Polovina et al. 2004, Mansfield et al. 2009) and in large juvenile and adult leatherbacks (James et al. 2005, Benson et al. 2011). Similar migrations by small juvenile leatherbacks are thus highly likely. As widely observed in other sea turtle species, and more generally in pelagic predators (Block et al. 2011), this equatorward autumn migration would be followed by a poleward spring migration as water temperatures increase and allow access to more productive, high-latitude foraging grounds. Such north-south migrations governed by thermotaxis and food avail- 
ability would occur in the predominantly eastward circulation of the central North Pacific so that juvenile leatherbacks would ultimately reach the United States Pacific coast, but probably later than in the passive drift scenario, as juveniles encounter weaker (but still eastward) currents while seasonally retreating towards the center of the subtropical gyre. To evaluate this effect, we performed a simple experiment in which, after 1 yr of pure passive drift, simulated Jamursba-Medi juveniles drifting in the North Pacific initiate seasonal migrations, actively swimming southward during fall and northward during spring. As in the simulation of random swimming activity, a size-dependent displacement of $d\left(\mathrm{~km} \mathrm{~d}^{-1}\right)$ is used, with $d$ given by Eq. (1). This displacement is added every day to the current-induced drift, using the following algorithm:

- During spring: a displacement of $d\left(\mathrm{~km} \mathrm{~d}^{-1}\right)$ is applied towards the north; this displacement is not applied if it causes the simulated turtle to enter water with $T_{\mathrm{w}}<T_{\min }$

- During summer and winter: no displacement is added (pure drift)

- During fall: a displacement of $d\left(\mathrm{~km} \mathrm{~d}^{-1}\right)$ is applied towards south

With this simple algorithm we ensure that, during spring migration, no turtle moves northward faster than the $T_{\min }$ isotherm. Also, with daily meridional movements of around $35 \mathrm{~km} \mathrm{~d}^{-1}$ sustained during the 3 spring or fall months, the oldest simulated individuals (5 to 6 yr old) undertake seasonal migrations spanning nearly $30^{\circ}$ in latitude, from about $40^{\circ} \mathrm{N}$ in summer to $10^{\circ} \mathrm{N}$ in winter. Such a large migration range is consistent with the amplitude of the seasonal migrations observed in adults tracked from California (Benson et al. 2011).

Results of the simulation with added seasonal migration movements indicate that, at the end of the sixth year of simulation, only $10 \%$ of the simulated turtles heading towards California have reached the longitude of Hawaii $\left(155^{\circ} \mathrm{W}\right)$, and $<1 \%$ have reached $145^{\circ} \mathrm{W}$. This confirms that seasonal migrations effectively slow down the progression of simulated juveniles towards the eastern part of the Pacific basin and suggests that the entire journey to the United States Pacific coast would average 8 to $9 \mathrm{yr}$ versus $5 \mathrm{yr}$ for the passive drift simulation. This slower drift scenario is actually more consistent with the observed size distribution of leatherbacks in the central and eastern North Pacific. Indeed, the recorded sizes of leatherbacks incidentally caught by the Hawaiibased pelagic longline fishery (Fig. 10) show that only large leatherbacks (SCL > $1.3 \mathrm{~m}$ ), likely much older than $5 \mathrm{yr}$, are observed east of $150^{\circ} \mathrm{W}$. Individuals observed close to the coast of California are also in this size range (Harris et al. 2011). This indicates that $5 \mathrm{yr}$ old leatherbacks are unlikely to be present in the easternmost part of the basin. Medium sized individuals $(1 \mathrm{~m} \leq \mathrm{SCL} \leq 1.3 \mathrm{~m})$, however, are incidentally caught in the NPTZ at longitudes reaching nearly $150^{\circ} \mathrm{W}$, suggesting that 5 to $10 \mathrm{yr}$ old individuals are present in the central Pacific, in agreement with the slower drift scenario. Interestingly, also, bycatch of small leatherbacks is reported south of Hawaii in sizes range between 50 and $87.5 \mathrm{~cm}$, corresponding to 2 to $4 \mathrm{yr}$ old juveniles (Jones et al. 2011). All were captured at locations centered around $10^{\circ} \mathrm{N}, 165^{\circ} \mathrm{W}$, which is the area where a number of simulated 2 to $3 \mathrm{yr}$ old juveniles (either purely drifting or drifting and randomly foraging) finish their ride in the NECC before recirculating westward in the NEC. This suggests that passive or nearly passive drift in the warm waters of the NECC might explain how these small individuals reached the area where they were caught.

All together this suggests that juvenile western Pacific leatherback turtles migrating in the North Pacific might act as nearly passive drifters for a period of 1 or $2 \mathrm{yr}$, until oceanic circulation takes them into areas where $T_{\mathrm{w}}$ approaches $T_{\min }$ and induces active swimming towards warmer waters. From this point, displacements will result from a combination of current-induced drift and habitatdriven movement based on temperature and food availability. A similar scenario can be expected in the South Pacific where nearly $75 \%$ of the simulated Kamiali juveniles freely drifting south of $30^{\circ} \mathrm{S}$ encounter $T_{\mathrm{w}}<T_{\min }$. Interestingly, such a scenario would not drastically modify the spatial distribution of juveniles simulated under the passive drift hypothesis. It would essentially add north-south, back and forth, movements to the already simulated drift movements. This would broaden (essentially equatorward) the latitudinal extent of the dispersal areas, but their longitudinal extent (and thus their penetration into the eastern part of the Pacific basin) would be less affected and still controlled by the strength of the circulation in the subtropical gyres. The SP gyre being less developed and weaker than its NP counterpart (e.g. Stramma et al. 1995), our basic finding of a dichotomy between extensive dispersion in the North Pacific and dispersal limited to the western part of the South Pacific remains, and provides support for the LMG hypothesis. 


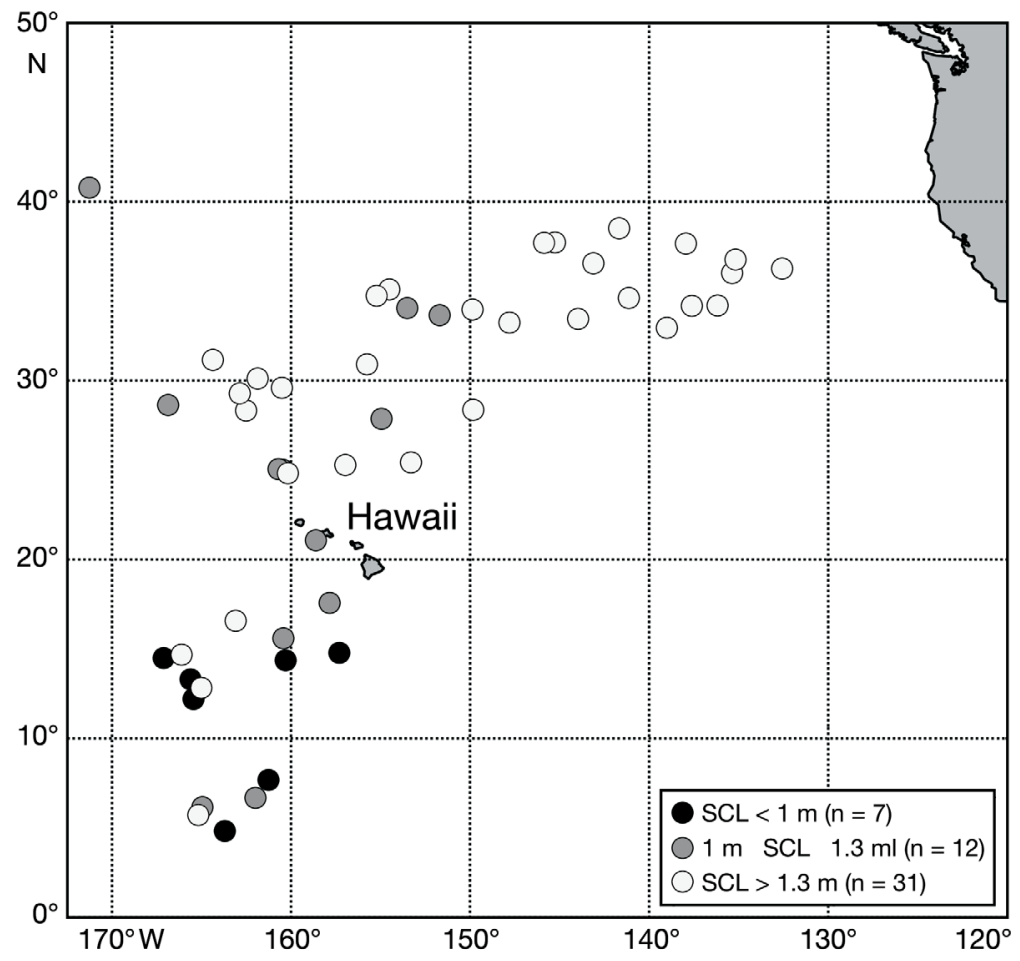

Fig. 10. Dermochelys coriacea. Spatial distribution of incidental catches of leatherbacks by the Hawaii-based pelagic longline fishery. These bycatch events were recorded by the NOAA Fisheries, Pacific Islands Regional Observer Program (Hawaii) between April 1994 and March 2011. Only the records including the position, date and size of a captured individual are featured here. All individuals with straight carapace length (SCL) $<1 \mathrm{~m}$ had their size precisely measured. Only an eyeball estimate of the size was available for larger individuals. This estimate is assumed to be equal to the SCL. Given the limited accuracy of such estimates, only 3 broad classes of sizes are distinguished here. $\mathrm{n}=$ sample size

\section{SUMMARY AND CONCLUSIONS}

The current paper presents the first model-based investigation of the oceanic dispersal of juvenile western Pacific leatherback turtles Dermochelys coriacea. Our passive drift simulations reveal a rare situation in which hatchlings emerging from the same nesting beach are likely to be entrained by highly variable currents into 3 widely different dispersal areas situated in the NP and SP and IO.

The IO dispersal scheme, so far not used by tracked adults, appears to be associated with very high juvenile mortality. Exposure to high predation and fisheries-induced mortality during the crossing of the Indonesian seas, relatively poor foraging habitats in the IO and a strenuous return journey against dominant currents probably all contribute to the low probability of survival by juveniles moving into this area. Our simulations indicate that the percentage of hatchlings drifting into the IC-IO area typically varies between 30 and $80 \%$, depending on the year of emergence, and suggests that interannual ocean variability may have a major impact on the global juvenile survival rate and thus on the evolution of the western Pacific leatherback population as a whole.

Our simulations also show that, within 1 to $2 \mathrm{yr}$, currents likely entrain many juveniles towards temperate regions where winter water temperatures drop well below the minimum temperature likely tolerated by such small turtles. This leads us to hypothesize that, after an initial period of mostly passive drift, juveniles must initiate active swimming towards lower latitudes before winter and back again towards higher latitudes, where food abounds, during spring. Such seasonal north-south migrations would significantly slow the eastward progression of individuals circulating in the North Pacific current. This slower drift scenario better explains the size distribution of leatherbacks incidentally caught by pelagic fisheries in the central and eastern North Pacific and the fact that only large individuals are observed off the United States Pacific coast.

The juvenile dispersal mechanism proposed here, combining passive drift movements with seasonal habitat-driven migrations might well apply to many other sea turtle populations. The juvenile dispersal mechanism proposed here, combining passive drift movements with seasonal habitat-driven migrations, might well apply to many other sea turtle populations. It shall serve as a framework for developing more complete models of juvenile sea turtle dispersal, explicitly including the responses of animals to their environment. Such models will be refined as new direct observations of juveniles' movements and more detailed studies of their thermal ecology become available.

Acknowledgements. We thank Mercator Ocean for making the GLORYS-1 global ocean reanalysis available to us. Special thanks to N. Ferry for answering all questions concerning this reanalysis, to B. Blanke and N. Grima for their support on the ARIANE software, to J. Willson for extracting and providing leatherbacks' incidental catch data, to B. Calmettes for assistance with data management, processing and visualization, and to P. Lehodey and M. Abecassis for useful discussions and comments on this manuscript. S.F. was supported by an AXA 'Young Talents' post-doctoral fellowship. 


\section{LITERATURE CITED}

Amorocho DF, Abreu-Grobois FA, Dutton PH, Reina RD (2012) Multiple distant origins for green sea turtles aggregating off Gorgona Island in the Colombian eastern Pacific. PLoS ONE 7:e31486

Arruda WZ, Nof D (2003) The Mindanao and Halmahera eddies - twin eddies induced by nonlinearities. J Phys Oceanogr 33:2815-2830

> Atmadipoera A, Molcard R, Madec G, Wijffels S and others (2009) Characteristics and variability of the Indonesian throughflow water at the outflow straits. Deep-Sea Res I 56:1942-1954

Bass AL, Epperly SP, Braun-McNeill J (2006) Green turtle (Chelonia mydas) foraging and nesting aggregations in the Caribbean and Atlantic: impact of currents and behavior on dispersal. J Hered 97:346-354

> Behrenfeld MJ, Falkowski PG (1997) Photosynthetic rates derived from satellite-based chlorophyll concentration. Limnol Oceanogr 42:1-20

> Benson SR, Dutton PH, Hitipeuw C, Samber B, Bakarbessy J, Parker D (2007a) Post-nesting migrations of leatherback turtles (Dermochelys coriacea) from JamursbaMedi, Bird's Head Peninsula, Indonesia. Chelonian Conserv Biol 6:150-154

> Benson SR, Kisokau KM, Ambio L, Rei V, Dutton PH, Parker D (2007b) Beach use, internesting movement, and migration of leatherback turtles, Dermochelys coriacea, nesting on the north coast of Papua New Guinea. Chelonian Conserv Biol 6:7-14

Benson SR, Forney KA, Harvey JT, Carretta JV, Dutton PH (2007c) Abundance, distribution and habitat of leatherback turtles (Dermochelys coriacea) off California, 1990-2003. Fish Bull 105:337-347

Benson SR, Eguchi T, Foley D, Forney KA and others (2011) Large-scale movements and high-use areas of western Pacific leatherback turtles, Dermochelys coriacea. Ecosphere 2:art84. doi:10.1890/ES11-00053.1

Berthold P, Helbig AJ (1992) The genetics of bird migration: stimulus, timing and direction. Ibis 134:35-40

- Blanke B, Raynaud S (1997) Kinematics of the Pacific Equatorial Undercurrent: a Eulerian and Lagrangian approach from GCM results. J Phys Oceanogr 27:1038-1053

Block BA, Jonsen ID, Jorgensen SJ, Winship AJ and others (2011) Tracking apex marine predator movements in a dynamic ocean. Nature 475:86-90

Blumenthal JM, Abreu-Grobois FA, Austin TJ, Broderick $\mathrm{AC}$ and others (2009) Turtle groups or turtle soup: dispersal patterns of hawksbill turtles in the Caribbean. Mol Ecol 18:4841-4853

Bolten AB, Martins HR, Bjorndal KA, Gordon J (1993) Size distribution of pelagic-stage loggerhead sea turtles (Caretta caretta) in the waters around the Azores and Madeira. Arquipélago-Bulletin of the University of the Azores 11A:49-54

> Bolten AB, Bjorndal KA, Martins HR, Dellinger T, Biscoito MJ, Encalada SE, Bowen BW (1998) Transatlantic developmental migrations of loggerhead sea turtles demonstrated by mtDNA sequence analysis. Ecol Appl 8:1-7

Bostrom BL, Jones DR (2007) Exercise warms adult leatherback turtles. Comp Biochem Physiol A 147:323-331

Bostrom BL, Jones TT, Hastings M, Jones DR (2010) Behaviour and physiology: the thermal strategy of leatherback turtles. PLoS ONE 5:e13925

Bowen BW, Karl SA (1996) Population genetics, phylogeog- raphy, and molecular evolution. In: Lutz PL, Musick JA (eds) The biology of sea turtles. CRC Press, Boca Raton, FL, p 29-50

Bowen BW, Abreu-Grobois FA, Balazs GH, Kamezaki N, Limpus CJ, Ferl RJ (1995) Trans-Pacific migrations of the loggerhead turtle (Caretta caretta) demonstrated with mitochondrial DNA markers. Proc Natl Acad Sci USA 92:3731-3734

> Bowen BW, Grant WS, Hillis-Starr Z, Shaver DJ, Bjorndal KA, Bolten AB, Bass AL (2007) Mixed-stock analysis reveals the migration of juvenile hawksbill turtles (Eretmochelys imbricata) in the Caribbean Sea. Mol Ecol 16:49-60

Bowen MM, Wilkin JL, Emery WL (2005) Variability and forcing of the East Australian Current. J Geophys Res C:110. doi:10.1029/2004/JC002533

- Boyle MC, Fitzsimmons NN, Limpus CJ, Kelez S, VelezZuazo X, Waycott M (2009) Evidence for transoceanic migrations by loggerhead sea turtles in the southern Pacific Ocean. Proc Biol Sci 276:1993-1999

Broderick AC, Coyne MS, Fuller WJ, Glen F, Godley BJ (2007) Fidelity and over-wintering of sea-turtles. Proc Biol Sci 274:1533-1539

Carr A (1986a) The sea turtle: so excellent a fish. University of Texas Press, Austin, TX

Carr A (1986b) Rips, FADS and little loggerheads. Bioscience 36:92-100

> Carreras C, Pont S, Maffuci F, Pascual M and others (2006) Genetic structuring of immature loggerhead turtles (Caretta caretta) in the Mediterranean Sea reflects water circulation patterns. Mar Biol 149:1269-1279

> Chong JC, Sprintall J, Hautala S, Morawitz WL, Bray NA, Pandoe W (2000) Shallow throughflow variability in the outflow straits of Indonesia. Geophys Res Lett 27: $125-128$

Collard SB, Ogren LH (1990) Dispersal scenarios for pelagic post-hatchling sea turtles. Bull Mar Sci 47:233-243

> Davenport J (1987) Locomotion in hatchling leatherback turtles Dermochelys coriacea. J Zool (Lond) 212:85-101

$>$ Donoso M, Dutton PH (2010) Sea turtle bycatch in the Chilean pelagic longline fishery in the southeastern Pacific: opportunities for conservation. Biol Conserv 143: 2672-2684

Dutton PH (2007) Satellite telemetry combined with genetic analysis as tools for study of sea turtle ecology: new discoveries and future possibilities. In: Mast RB, Hutchinson BJ, Hutchinson AH (eds) Proceedings of the 24th annual symposium on sea turtle biology and conservation. NOAA Tech. Memo. NMFS-SEFSC-567, US Dept Commerce, Washington, DC, p 71

> Dutton PH, Bowen BW, Owens DW, Barragan A, Davis SK (1999) Global phylogeography of the leatherback turtle (Dermochelys coriacea). J Zool (Lond) 248:397-409

Dutton PH, Frey A, LeRoux R, Balazs G (2000) Molecular ecology of leatherback turtles in the Pacific. In: Pilcher N, Ismael G (eds) Sea turtles of the Indo-Pacific. Research, management and conservation. ASEAN Academic Press, London, p 248-253

> Dutton DL, Dutton PH, Chaloupka M, Boulon R (2005) Increase of a Caribbean leatherback turtle Dermochelys coriacea nesting population linked to long-term nest protection. Biol Conserv 126:186-194

Dutton PH, Hitipeuw C, Zein M, Benson SR and others (2007) Status and genetic structure of nesting populations of leatherback turtles (Dermochelys coriacea) in the 
western Pacific. Chelonian Conserv Biol 6:47-53

Eckert SA (2002) Distribution of juvenile leatherback sea turtle Dermochelys coriacea sightings. Mar Ecol Prog Ser 230:289-293

$>$ Eckert SA (2006) High-use oceanic areas for Atlantic leatherback sea turtles (Dermochelys coriacea) as identified using satellite telemetered location and dive information. Mar Biol 149:1257-1267

FAO (Food and Agricultural Organization) (2009) The state of world fisheries and aquaculture 2008. FAO, Rome

Ferraroli S, George JY, Gaspar P, Le Maho Y (2004) Where leatherback turtles meet fisheries. Nature 429:521-522

Ferry N, Greiner E, Garric G, Penduff T, Tréguier AM, Reverdin G (2008) GLORYS-1 reference manual for Stream 1 (2002-2007). Mercator-Ocean Report, Toulouse

Ferry N, Parent L, Garric G, Barnier B, Jourdain NC and the Mercator Ocean team (2010) Mercator global eddy permitting ocean reanalysis GLORYS1V1: description and results. Mercator Q Newsl 36:15-27

Fossette S, Hobson VJ, Girard C, Calmettes B, Gaspar P, Georges JY, Hays GC (2010a) Spatio-temporal foraging patterns of a giant zooplanktivore, the leatherback turtle. J Mar Syst 81:225-234

Fossette S, Girard C, Lopez-Mendilaharsu M, Miller P and others (2010b) Atlantic migratory paths and temporary residence areas. PLoS ONE 5:e13908

> Freake MJ, Muheim R, Phillips JB (2006) Magnetic map in animals. A theory comes of age? Q Rev Biol 81:327-347

Gaspar P, George JY, Fossette S, Lenoble A, Ferraroli S, Le Maho Y (2006) Marine animal behaviour: neglecting ocean currents can lead us up the wrong track. Proc Biol Sci 273:2697-2702

- Gill BJ (1997) Records of turtles and sea snakes in New Zealand, 1837-1996. NZ J Mar Freshw Res 31:477-486

Gilman E, Gearhart J, Price B, Eckert S and others (2009) Mitigating sea turtle by-catch in coastal passive net fisheries. Fish Fish 11:57-88

> Godley BJ, Barbosa C, Bruford M, Broderick AC and others (2010) Unravelling the migratory connectivity in marine turtles using multiple methods. J Appl Ecol 47:769-778

> Gordon AL (2005) Oceanography of the Indonesian seas and their throughflow. Oceanography (Wash DC) 18:14-27

> Hamann M, Godfrey MH, Seminoff JA, Arthur K and others (2010) Global research priorities for sea turtles: informing management and conservation in the 21st century. Endang Species Res 11:245-269

- Harris HS, Benson SR, Gilard KV, Poppenga RH, Work TM, Dutton PH, Mazr JAK (2011) Comparative health assessment of western Pacific leatherback turtles (Dermochelys coriacea) foraging off the coast of California, 2005-2007. J Wildl Dis 47:321-337

- Hays GC, Marsh R (1997) Estimating the age of juvenile loggerhead sea turtles in the North Atlantic. Can J Zool 75: 40-46

> Hays GC, Fossette S, Katselidis KA, Mariani P, Schofield G (2010) Ontogenetic development of migration: Lagrangian drift trajectories suggest a new paradigm for sea turtles. J R Soc Interface 7:1319-1327

> Hitipeuw C, Dutton PH, Benson SR, Thebu J, Bakarbessy J (2007) Population status and internesting movement of leatherback turtles, Dermochelys coriacea, nesting on the northwest coast of Papua, Indonesia. Chelonian Conserv Biol 6:28-36

James MC, Ottensmeyer CA, Myers RA (2005) Identification of high-use habitats and threats to leatherback sea tur- tles in northern waters: new directions for conservation. Ecol Lett 8:195-201

Jones TT, Hastings MD, Bostrom BL, Pauly D, Jones DR (2011) Growth of captive leatherback turtles, Dermochelys coriacea with inferences on growth in the wild: implications for population decline and recovery. J Exp Mar Biol Ecol 399:84-92

Kessler W, Gourdeau L (2007) The annual cycle of circulation of the southwest subtropical Pacific, analyzed in an ocean GCM. J Phys Oceanogr 37:1610-1627

Kuroda Y (2000) Variability of currents off the northern coast of New Guinea. J Oceanogr 56:103-116

Lewison RL, Freeman SA, Crowder LB (2004) Quantifying the effects of fisheries on threatened species: the impact of pelagic longlines on loggerhead and leatherback sea turtles. Ecol Lett 7:221-231

> Lilley MKS, Beggs SE, Doyle TK, Hobson VJ, Stromberg KHP, Hays GC (2011) Global patterns of epipelagic gelatinous zooplankton biomass. Mar Biol 158:2429-2436

Limpus CJ (2009) A biological review of Australian marine turtles. 6. Leatherback turtle, Dermochelys coriacea (Vandelli). Environmental Protection Agency of the Queensland Government, Brisbane

Limpus CJ, Miller JD, Parmenter CJ, Reimer D, McLahan N, Webb R (1992) Migration of green (Chelonia mydas) and loggerhead (Caretta caretta) turtles to and from eastern Australian rookeries. Wildl Res 19:347-358

> Lohmann KJ, Putman NF, Lohmann CMF (2008) Geomagnetic imprinting: a unifying hypothesis of long-distance natal homing in salmon and sea turtles. Proc Natl Acad Sci USA 105:19096-19101

> Lohmann KJ, Lohmann CMF (1994) Detection of magnetic inclination angle by sea turtles: a possible mechanism for determining latitude. J Exp Biol 194:23-32

> Lohmann KJ, Lohmann CMF (1996) Detection of magnetic field intensity by sea turtles. Nature 380:59-61

> Lohmann KJ, Hester JT, Lohmann CMF (1999) Longdistance navigation in sea turtles. Ethol Ecol Evol 11:1-23

Lohmann KJ, Cain SD, Dodge SA, Lohmann CMF (2001) Regional magnetic fields as navigational markers for sea turtles. Science 294:364-366

> Luschi P, Hays GC, Del Seppia C, Marsh R, Papi F (1998) The navigational feats of green sea turtles migrating from Ascension Island investigated by satellite telemetry. Proc Biol Sci 265:2279-2284

> Mansfield KL, Saba VS, Keinath JA, Musick JA (2009) Satellite tracking reveals a dichotomy in migration strategies among juvenile loggerhead turtles in the Northwest Atlantic. Mar Biol 156:2555-2570

> McMahon CR, Hays GC (2006) Thermal niche, large-scale movements and implications of climate change for a critically endangered marine vertebrate. Glob Change Biol 12:1330-1338

Meylan AB, Bowen BW, Avise JC (1990) A genetic test of the natal homing versus social facilitation models for green turtle migration. Science 248:724-727

Monzón-Argüello C, López-Jurado LF, Rico C, Marco A, López P, Hays GC, Lee PLM (2010) Evidence from genetic and Lagrangian drifter data for transatlantic transport of small juvenile green turtles. J Biogeogr 37 : 1752-1766

Musick JA, Limpus CJ (1997) Habitat utilization and migration in juvenile sea turtles. In: Lutz PL, Musick JA (eds) The biology of sea turtles. CRC Press, Boca Raton, FL, p 137-164 
Papi F, Liew HC, Luschi P, Chan EH (1995) Long-range migratory travel of a green turtle tracked by satellite: evidence for navigational ability in the open ocean. Mar Biol 122:171-175

Polovina JJ, Howell E, Kobayashi DR, Seki MP (2001) The transition zone chlorophyll front, a dynamic global feature defining migration and forage habitat for marine resources. Prog Oceanogr 49:469-483

Polovina JJ, Balasz GH, Howell EA, Parker DM, Seki MP, Dutton PH (2004) Forage and migration habitat of loggerhead (Caretta caretta) and olive ridley (Lepidochelys coriacea) sea turtles in the central North Pacific Ocean. Fish Oceanogr 13:36-51

Putman NF, Shay TJ, Lohmann KJ (2010) Is the geographic distribution of nesting in the Kemp's ridley turtle shaped by the migratory needs of offspring? Integr Comp Biol 50: 305-314

Saba VS, Shillinger GL, Swithenbank AM, Block BA, Spotila JR, Musick JA, Paladino FV (2008) An oceanographic context for the foraging ecology of eastern Pacific leatherback turtles: consequences of ENSO. Deep-Sea Res I 55:646-660

Schofield G, Hobson VJ, Fossette S, Lilley MKS, Katselis KA, Hays GC (2010) Fidelity to foraging sites, consistency of migration routes and habitat modulation of home range by sea turtles. Divers Distrib 16:840-853

Scott R, Marsh R, Hays GC (2012) A little movement orientated to the geomagnetic field makes a big difference in strong flows. Mar Biol 159:481-488

Seney EE, Higgins BM, Landry AM (2010) Satellite transmitter attachment techniques for small juvenile sea turtles. J Exp Mar Biol Ecol 384:61-67

Sprintall J, Wijffels SE, Molcard R, Jaya I (2009) Direct estimates of Indonesian throughflow entering the Indian

Submitted: September 30, 2011; Accepted: February 24, 2012
Ocean 2004-2006. J Geophys Res C:114. doi:10.1029/ 2008JC005257

Stramma L, Lutjeharms JRE (1997) The flow field of the subtropical gyre of the South Indian Ocean. J Geophys Res C 102:5513-5530

Stramma L, Peterson RG, Tomczak M (1995) The South Pacific Current. J Phys Oceanogr 25:77-91

Tucker AD, Frazer NB (1991) Reproductive variations in leatherback turtles, Dermochelys coriacea, at Culebra National Wildlife Refuge Puerto Rico. Herpetologica 47: $115-124$

Ueki I, Kashino J, Kuroda Y (2003) Observations of current variations off the New Guinea coast including the 19971998 El Niño period and their relationship with Sverdrup transport. J Geophys Res C:108. doi:10.1029/2002 JC001611

> Wijffels SE, Meyers G, Godfrey JS (2008) A 20-yr average of the Indonesian throughflow: regional currents and the interbasin exchange. J Phys Oceanogr 38:1965-1977

> Witherington BE (2002) Ecology of neonate loggerhead turtles inhabiting lines of downwelling near a Gulf Stream front. Mar Biol 140:843-853

Witt MJ, Broderick AC, Johns DJ, Martin C, Penrose R, Hoogmoed MS, Godley BJ (2007) Prey landscapes help identify potential foraging habitats for leatherback turtles in the NE Atlantic. Mar Ecol Prog Ser 337:231-244

> Wolanski E, Ridd P, Inoue M (1988) Currents through Torres Strait. J Phys Oceanogr 18:1535-1545

Wyneken J (1997) Sea turtle locomotion: mechanisms, behavior and energetic. In: Lutz PL, Musick JA (eds) The biology of sea turtles. CRC Press, Boca Raton, FL, p 165-198

> Wyneken J, Salmon M (1992) Frenzy and postfrenzy swimming activity in loggerhead, green and leatherback hatchling sea turtles. Copeia 1992:478-484

Proofs received from author(s): June 9, 2012 